\title{
Global burden of Clostridium difficile infections: a systematic review and meta-analysis
}

\author{
Evelyn Balsells ${ }^{1, *}$, Ting Shi1 ${ }^{1, *}$, \\ Callum Leese', Iona Lyell', \\ John Burrows ${ }^{1}$, Camilla \\ Wiuff ${ }^{2}$, Harry Campbell ${ }^{1}$, \\ Moe H Kyaw ${ }^{3, * *}$, Harish Nair ${ }^{1, * *}$ \\ ${ }^{1}$ Centre for Global Health Research, \\ Usher Institute of Population Health \\ Sciences and Informatics, University of \\ Edinburgh, Edinburgh, UK \\ ${ }^{2}$ Health Protection Scotland, \\ Glasgow, UK \\ ${ }^{3}$ Sanofi Pasteur, Swiftwater, \\ Pennsylvania, USA \\ *Joint first authorship \\ **Joint last authorship
}

Background Clostridium difficile is a leading cause of morbidity and mortality in several countries. However, there are limited evidence characterizing its role as a global public health problem. We conducted a systematic review to provide a comprehensive overview of $C$. difficile infections (CDI) rates.

Methods Seven databases were searched (January 2016) to identify studies and surveillance reports published between 2005 and 2015 reporting CDI incidence rates. CDI incidence rates for health care facility-associated (HCF), hospital onset-health care facility-associated, medical or general intensive care unit (ICU), internal medicine (IM), long-term care facility (LTCF), and community-associated (CA) were extracted and standardized. Meta-analysis was conducted using a random effects model.

Results 229 publications, with data from 41 countries, were included. The overall rate of HCF-CDI was 2.24 (95\% confidence interval CI = 1.663.03) per 1000 admissions/y and $3.54(95 \% \mathrm{CI}=3.19-3.92)$ per $10000 \mathrm{pa}-$ tient-days/y. Estimated rates for CDI with onset in ICU or IM wards were $11.08(95 \% \mathrm{CI}=7.19-17.08)$ and $10.80(95 \% \mathrm{CI}=3.15-37.06)$ per 1000 admission/y, respectively. Rates for CA-CDI were lower: 0.55 (95\% CI =0.132.37) per 1000 admissions/y. CDI rates were generally higher in North America and among the elderly but similar rates were identified in other regions and age groups.

Conclusions Our review highlights the widespread burden of disease of C. difficile, evidence gaps, and the need for sustainable surveillance of CDI in the health care setting and the community.

Clostridium difficile is a leading cause of health care-associated infections (HAIs) and an important public health threat. C. difficile has been associated with substantial morbidity and mortality worldwide and among individuals of all ages beyond the traditionally recognized at-risk groups (eg, elderly, hospitalized patients, or those under antimicrobial therapy) [1]. In the United States, C. difficile caused an estimated half a million infections and 29000 deaths in 2012 [2]. Almost two thirds of these were associated with inpatient care, and more than $80 \%$ of these deaths occurred in those 65 years and over [2]. Challenges remain to control incidence of $C$. difficile infections (CDI) rates in other world regions such as Europe [3-5] and Asia [6]. It is estimated that approximately 40000 cases among inpatients are potentially underdiagnosed each year in Europe [5]. Furthermore, recurrence of CDI is estimated to occur among a considerable percentage of cases (approximately 20\%-30\%) [7]. Though the global health care costs associated with CDI are not known, these are likely to be substantial with estimates suggesting attributable costs of US\$ 5.4-6.3 billion per year in the United States [8]. 
Considering the evolving epidemiology of $C$. difficile morbidity and mortality, global challenges regarding antibiotic stewardship and limited alternative preventative options for CDI, it is important to assess its burden to inform public health action. The emergence of hyper virulent strain PCR ribotype 027/NAP1, significant increases in incidence of hospitalizations associated with C. difficile by the mid-2000s, and outbreaks of CDI in hospitals globally are examples of the major impact $C$. difficile can have on health care systems [1,9-12]. Through the implementation of standardized surveillance case definitions, a considerable proportion of cases of CDI occurring outside hospitals has also been identified [1,13-15]. Increased awareness of the role of $C$. difficile as a global health problem is required to reduce morbidity and control rates of CDI $[16,17]$. However, there are limited evidence characterizing its role as a global public health problem. We aimed to conduct a comprehensive examination of globally reported rates of CDI incidence, in order to develop baseline epidemiological estimates of incidence and identify characteristics and gaps in the available evidence base.

\section{METHODS}

\section{Identification of eligible publications}

We searched seven electronic databases (Medline, Embase, Global Health (through Ovid), CINAHL, LILACS, WHO Library, and Web of Science) in January 2016 to identify publications reporting incidence rates of CDI. Search strategies were developed with the assistance of a medical librarian and included a combination of MeSH and keywords relevant for CDI and incidence or burden of disease. An internet search to identify the most recent data from national surveillance reports was also conducted to supplement evidence from published literature (Table S1 in Online Supplementary Document). Details on eligibility criteria for the review are described in Table 1. Two reviewers (EB, TS) screened the records obtained through electronic medical databases and identified articles that met the inclusion criteria. We included studies and surveillance reports with a publication year between 2005 and 2015 inclusive and reporting CDI cases identified through positive laboratory assay or endoscopic findings using surveillance case definitions [18] or administratively coded CDI hospitalizations (eg, International Classification of Diseases (ICD) ICD-9-ICM=00845.0 or ICD-10 =A04.7). Studies focusing on recurrence, asymptomatic colonization or mortality, or those published in languages other than English or Spanish were excluded. We also excluded data from periods of outbreaks or from intervention arms of infection control studies.

\section{Data extraction}

Data from the included studies were extracted by at least two reviewers (EB, CL, JB, IL) using an Excel form which was piloted before its final use. Uncertainties or discrepancies on data extraction were resolved by discussion between extractors. We extracted data on the study setting, duration, and design,

Table 1. Eligibility criteria

\begin{tabular}{|c|}
\hline Inclusion criteria \\
\hline $\begin{array}{l}\text { Observational (during non-outbreak periods) or interventional studies (pre-intervention period) and national surveillance reports published between } \\
2005 \text { and } 2015 \text {. }\end{array}$ \\
\hline English and Spanish language (for peer-reviewed publications). \\
\hline $\begin{array}{l}\text { Publication reports rates of CDI incidence for individuals of all ages in any of the following settings: hospitals, medical intensive care units, internal } \\
\text { medicine wards, long term care facilities or nursing homes and in the community. }\end{array}$ \\
\hline $\begin{array}{l}\text { Case ascertainment methods and case definition compatible with current CDI surveillance (laboratory or histological-diagnosis) or administrative } \\
\text { coded hospitalizations (ICD9-9-CM:008.45; ICD-10:A04.7) are clearly reported. }\end{array}$ \\
\hline $\begin{array}{l}\text { Data on incidence of CDI rate can be extracted as an independent outcome and at least two of the following are available: number of cases during } \\
\text { study period, study population (denominator) or rate. }\end{array}$ \\
\hline Exclusion criteria: \\
\hline Articles published before 2005 or reporting data for a study population already considered in the review. \\
\hline Methods for case ascertainment are not clearly reported. \\
\hline Interventional before-and-after studies without clear background rate or studies reporting rates outbreak periods exclusively. \\
\hline $\begin{array}{l}\text { C. difficile assessed as a co-infection, composite outcome (eg, set of health care-associated infections), or defined as an adverse drug reaction or anti- } \\
\text { biotic associated diarrhoea without C. difficile laboratory/code confirmation. }\end{array}$ \\
\hline $\begin{array}{l}\text { Study population at risk from which cases were identified narrowed by a prior selection process (eg, only diarrheal patients, those on antibiotics, } \\
\text { co-morbidity-specific groups). }\end{array}$ \\
\hline
\end{tabular}


case ascertainment methods, and case definition details. Data were extracted in accordance to the following settings of CDI acquisition: health care facility-associated (HCF), hospital onset health care facility-associated (HO-HCF), community-associated (CA), any setting/unspecified CDI and for three selected high-risk settings: medical or general intensive care units (ICU), internal medicine wards (IM), and longterm care facilities (LTCF), including nursing homes. For ICD-coded hospitalizations, we included publications reporting the number of hospitalizations with CDI code as a primary and secondary diagnosis. or data extraction, incidence rates were collected based on number of CDI cases that adhered to recommended surveillance case definitions, but also included studies with modified case definitions if this was clearly reported. Authors of publications eligible for inclusion were contacted to obtain the number of cases if additional eligible categories were reported in order to enable inclusion in the meta-analysis. To minimize potential bias towards large studies in meta-analyses, data from multicentre publications were extracted per health care facility and counted as an individual data point. Studies with data from facilities also included in national surveillance or other multicentre publications were excluded to avoid potential duplication of the same study population. Depending on the case definition, incidence for the following metrics were extracted and standardized: number of CDI cases per admissions (per 1000 admissions per year), incidence density (per 10000 patient-days), and cumulative incidence of CDI cases over the total population at risk (per 100000 population per year).

\section{Statistical analysis}

The total number of CDI cases by admissions, total patient-days, or population for each category, rates and $95 \%$ confidence intervals (CI) were extracted from publications as reported by authors or calculated based on available data. The distribution of CDI incidence rates identified was summarized in terms of interquartile ranges and median values as follows: for HCF and HO-HCF (including high-risk settings: ICU, IM, and LTCF) in terms of incidence density and cases per admissions, and for CA, any or unspecified setting of acquisition, or ICD-coded hospitalization in terms of cases per admissions and cumulative incidence.

Rates of CDI incidence were pooled using the metan command in Stata version 14 (StataCorp, College Station, Texas, USA). When a publication reported different rates for the same study population using different case ascertainment methods (eg, based on review of patients or laboratory charts vs administrative records) we used the number of CDI cases where patient's records had been reviewed. A small value (0.05) was used as continuity correction to include rates with zero CDI cases in the meta-analysis. Estimates were developed using a random effects model, acknowledging the heterogeneity in observational studies conducted in diverse settings.

Where possible, we performed and reported subgroup meta-analyses by location (WHO regions; the Americas region was divided into North America and Latin America) and age group (children $[\leq 15$ years or pediatric hospitals], adults [ $\geq 15$ years], elderly [ $\geq 65$ years], and all or unspecified age [ $\geq 0-2$ years and studies without information on age or where children were not explicitly excluded]). Subgroup analyses were performed for categories with at least three different data points.

\section{RESULTS}

\section{Overview of included studies}

A total of 229 publications [2,11,12,19-244], including 14 national surveillance reports, were included from over 12000 publications assessed for eligibility. The literature review process is summarized in the PRISMA flowchart in Figure 1. Data extracted from each of the included studies are available in (Tables S2-S8 in Online Supplementary Document).

We included data on rates of CDI incidence from 41 countries. The majority of reports (195/229) were from Europe and North America. Incidence data eligible for inclusion from other regions: Western Pacific, Latin America, Eastern Mediterranean, and Africa were identified less frequently, and no reports from the South-East Asia region was included. Sub-analyses on CDI rates by world region are reported for Europe, North America and the Western Pacific regions for categories with suitable number of data points to conduct a meta-analysis.

Of the 229 publications included, 89 publications reported rates of HCF-CDI (incidence density and/ or cases per admissions) and 57 publications reported data for HO-HCF CDI (incidence density and/or 


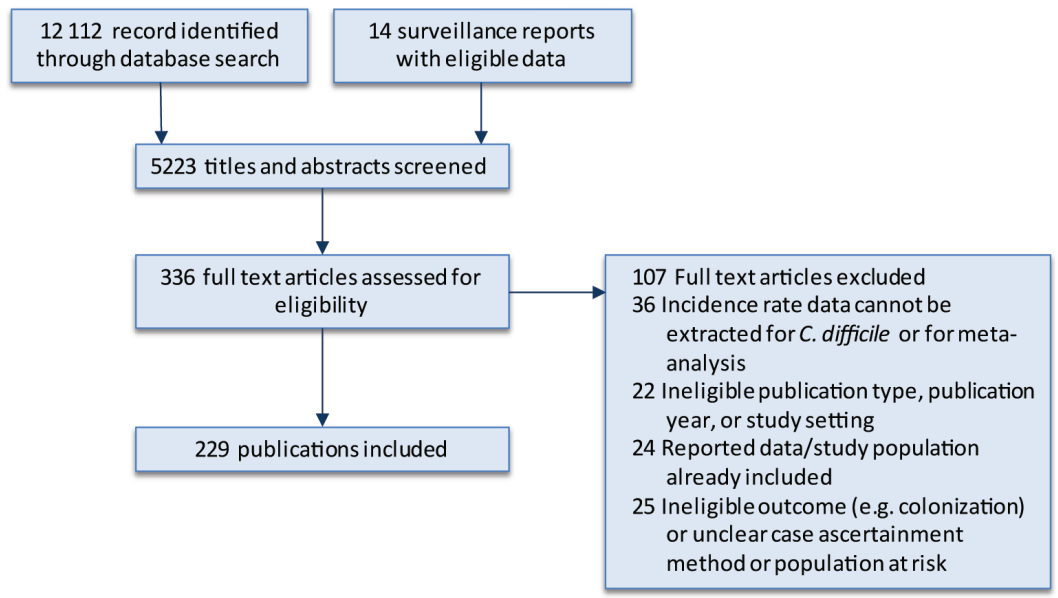

Figure 1. PRISMA flowchart.

cases per admissions). Rates of CA-CDI were reported in 39 publications with almost all data from countries in North America, Europe, and the Western Pacific. CDI in high-risk settings (ICU, IM, and LTCF; 56 publications) were also for the most part identified from countries in North America, Europe, Latin America and the Western Pacific. CDI rates for children and the elderly were reported in 37 and 33 publications, respectively. The number of individual data on rates for each of the CDI categories and age groups are presented in Table 2.

Regardless of metric, there were large variations in rates of CDI incidence across categories and age groups. Figure 2 depicts the median and range of all rates of CDI incidence reported in included studies in the review.

\section{Meta-analysis}

Table 3 shows the results from the meta-analyses, by CDI categories, regions and age groups.

\section{CDI cases per admission}

Incidence of CDI reported in individual studies ranged from 0 to 35.15 cases per 1000 admissions per year (Figure 2, panel a). The highest median number of CDI cases per admissions were reported from ICU and IM wards; with the highest meta-estimate for incidence rate (IR) of 11.08 (95\% CI $=7.19-17.08$ ) per 1000 admissions per year for ICU-onset CDI. Among all ages, meta-estimates rates of HO-HCF and HCF-CDI were similar ( $(\mathrm{R}=2.09$ (95\% CI $=1.16-3.74)$ per 1000 admissions per year and 2.24 (95\% $\mathrm{CI}=1.66-3.03)$ per 1000 admissions per year, respectively), and rates for CA-CDI were lower (IR $=0.55$ (95\% CI = 0.13-2.37) per 1000 admissions per year) (Table 3).

Estimates in the elderly were similar to those than for adults or higher compared to the other age groups (with children having the lowest incidence rates). Although regional level estimates were not strictly comparable, North America generally reported higher rates across CDI categories and age groups (Table 3).

\section{CDI incidence density}

CDI incidence density reported in individual studies ranged from 0.11 to 50.3 per 10000 patient-days (Figure 2, panel b). The highest estimated incidence density by meta-analysis was in the ICU and IM wards, the highest incidence rate $13.74(95 \% \mathrm{CI}=9.46-19.93)$ per 10000 patient-days was for ICU-onset CDI. The meta-analysis estimates for HO-HCF and HCF were similar ( $\mathrm{IR}=4.14$ (95\% CI=3.10-5.53) per 10000 patient-days and 3.54 (95\% CI=3.19-3.92) per 10000 patient-days, respectively), as was the incidence density in LTCF (IR=4.41 (95\% CI=2.36-8.23) per 10000 patient-days) (Table 3).

Meta-estimates for the four age categories were calculated for HCF-CDI incidence density, where the highest density was observed among the elderly ( $I R=10.95$ (95\% CI=5.08-23.59) per 10000 patient-days). Incidence density of HO-HCF CDI and HCF-CDI were also higher for adult populations compared to that in patients of all ages. Based on the limited data at regional level, we observed that North America had the highest CDI incidence density. 


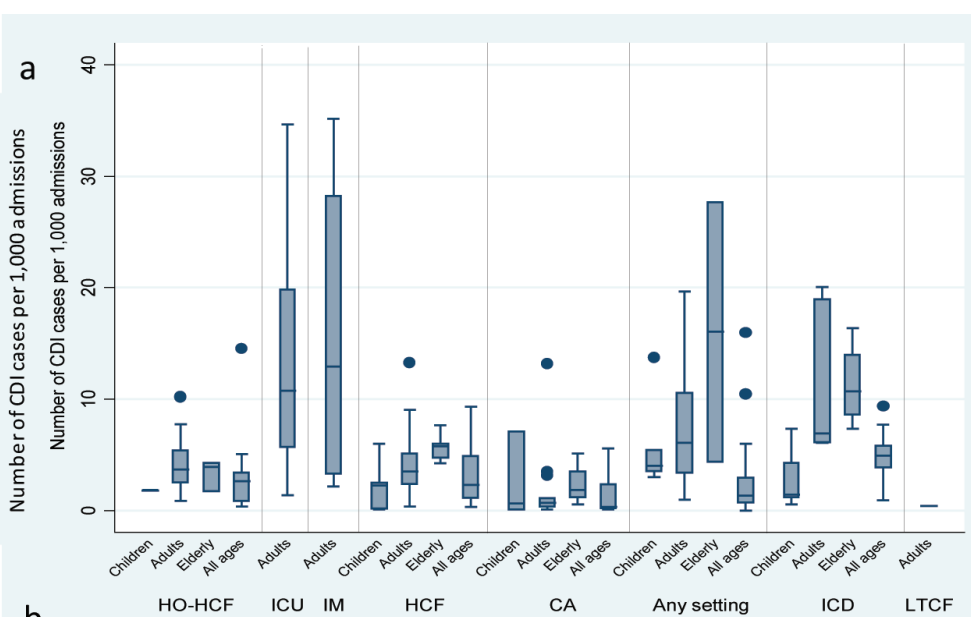

b

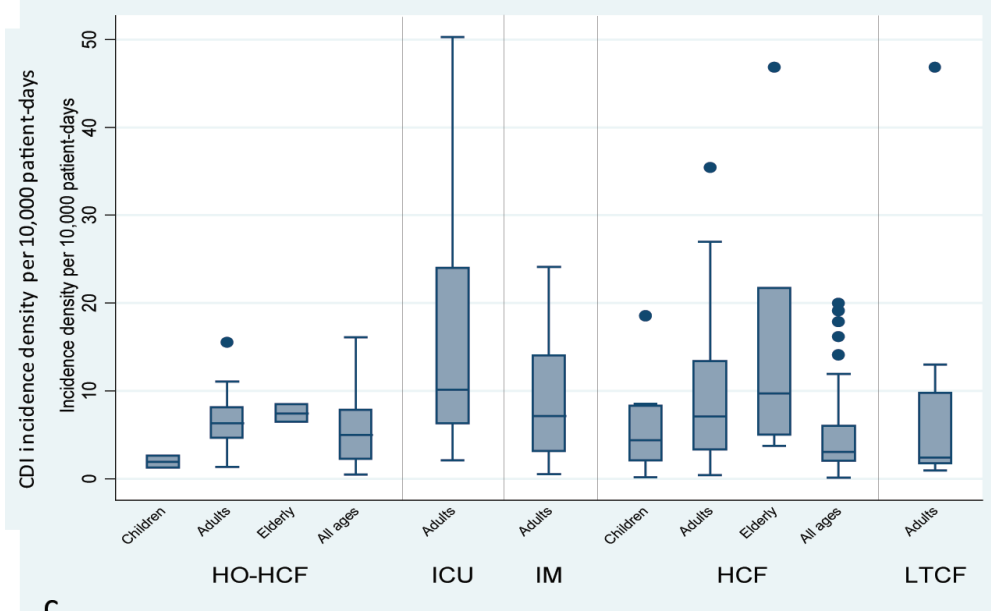

C

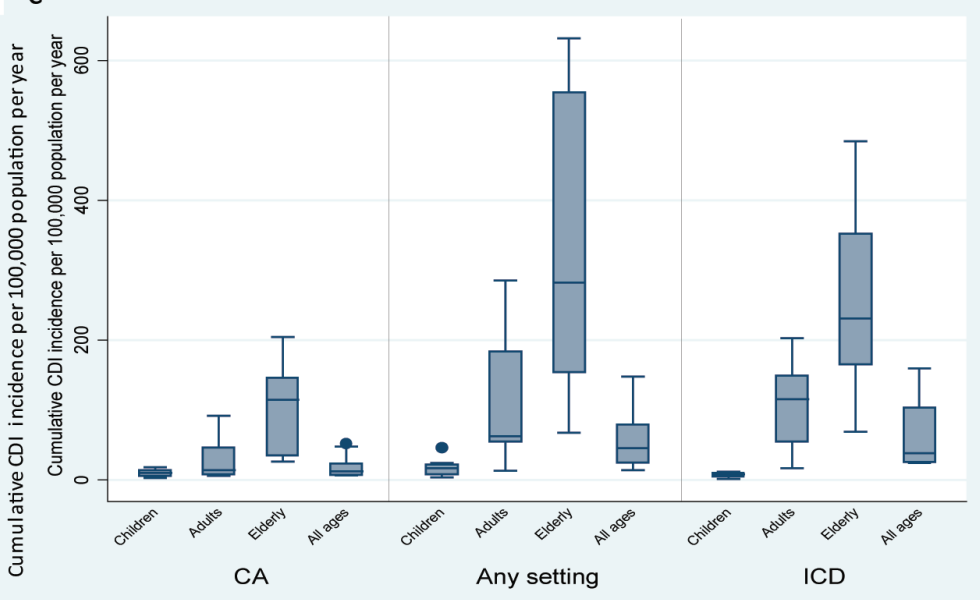

Figure 2. Distribution of CDI incidence rates by category and age groupI a) number of CDI cases per 1000 admissions per year, b) incidence density per 10000 patient-days, c) cumulative incidence per 100000 population per year. Abbreviations: CDI, Clostridium difficile infection; HO-HCF, hospital-onset health care facility-associated; ICU, intensive care unit; IM, internal medicine; HCF, health care facility-associated; CA, community-associated; ICD, international classification of diseases; LTCF, long term care facility.

\section{Cumulative incidence of CDI}

Cumulative incidence of CDI reported in individual studies ranged from 1.12 to 631.80 per 100000 population per year (Figure 2, panel c). The majority of data for cumulative incidence of CDI hospitalizations were available from large databases in the United States. Based on data from ICD- coded hospitalizations, the estimate of cumulative incidence rate for all ages is 49.36 (95\% CI $=34.01$ 71.75) per 100000 population per year. This estimate is similar to the rate based on CDI cases identified through positive laboratory assay and clinical criteria (IR $=41.94(95 \%$ $\mathrm{CI}=30.30-58.05)$ per 100000 population per year) (Table 3). For the latter, estimates from individual studies ranged from 13.42 per 100000 population per year in a study conducted in Spain in 2003 where national laboratories were surveyed to 147.20 per 100000 population per year in a study with sentinel surveillance in the United States where rates were adjusted for use of molecular laboratory assays. At the national level, increases in CDI hospitalization rates per 100000 population were reported, for instance, in Finland (from 16.0 in 1996 to 34.0 in 2004) [12], in Belgium (from 16.5 in 1999 to 44.3 in 2008), and in the United States (from 48.8 in 1999 to 114.6 in 2008) [11].

Where meta-analysis by age groups was possible, the results for the cumulative incidence for the elderly was higher compared with the other age groups; for any CDI (regardless of setting of acquisition), the overall estimate from meta-analysis was 323.32 (95\% $\mathrm{CI}=217.82-479.91)$ per 100000 population per year. Europe had the highest estimates of cumulative incidence rate CA-CDI in all age groups, though confidence intervals overlap with the estimate for North America.

\section{DISCUSSION}

The aim of this study was to examine reports of CDI incidence rates in order to develop an overall estimate and to identify gaps in the current evidence base globally. We found variations of CDI occurrence in terms of rates, within categories as well as between world regions. From our meta-analyses, the estimated
was 2.24 per 1000 admissions per year and overall incidence rate of HCF-CDI for patients of all ages was 2.24 per 1000 admissions per year and 3.54 per 10000 patient-days.

The implementation of robust surveillance systems is important to ascertain the burden of CDI across and to help identify any future changes in rates $[2,14]$. Through our review of the literature, we found that the highest rates of CDI for the majority of categories assessed were reported in North America. It 


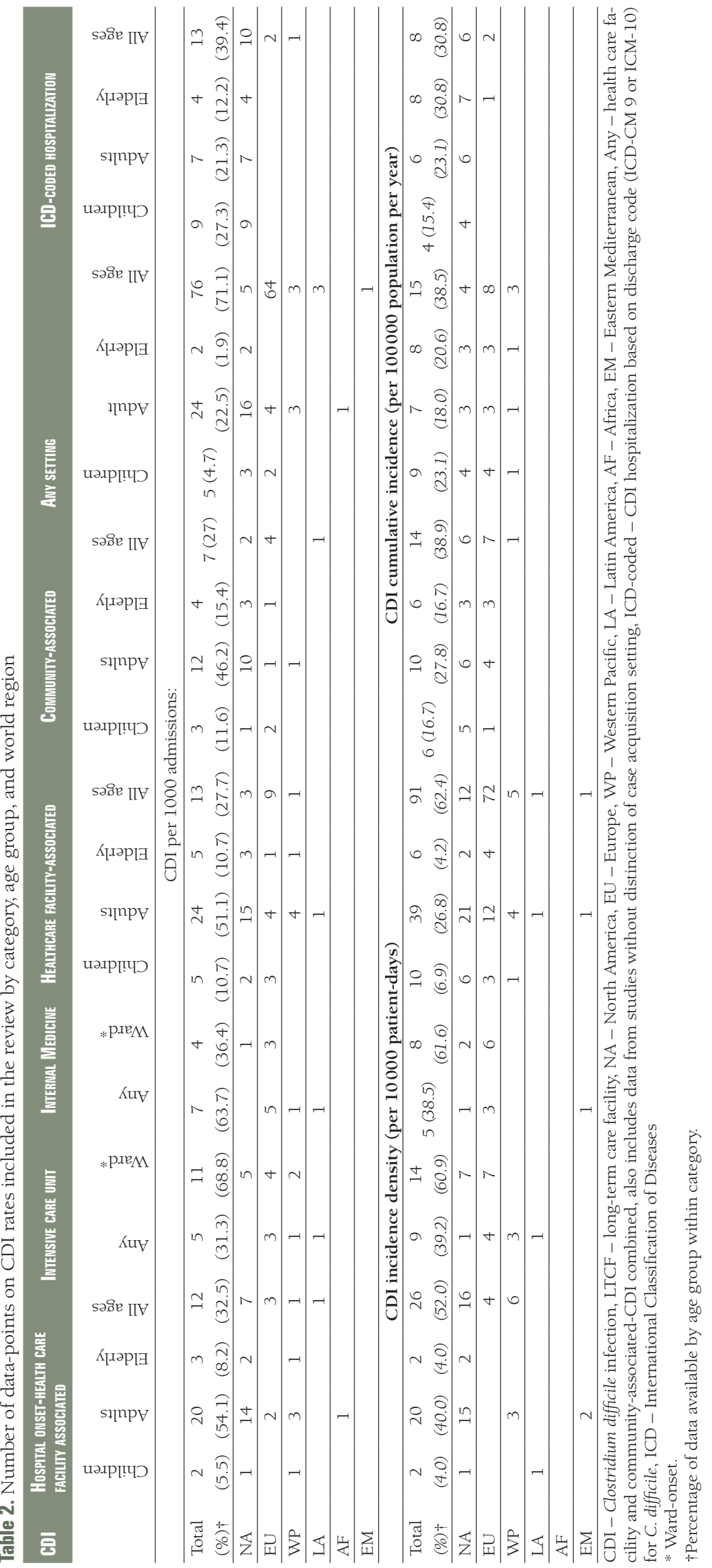

is likely that this finding is due to improvements in case detection and influenced by the use of high-sensitivity testing methods such as nucleic acid amplification testing which can lead to overestimation of CDI rates [2,149,245]. In Europe, our meta-estimate for health care-associated CDI density rates (3.14 [95\% CI $=2.80-3.53]$ per 10000 patient-days) is similar to estimates from regional surveys in 2005, 2008 and 201213 [3-5] (for which the overall estimate is $4.08(95 \% \mathrm{CI}=3.52-4.74)$ per 10000 patient days when data are analyzed by meta-analysis, (Appendix S9 in Online Supplementary Document). Our meta-estimate is also similar to the median rate based on aggregate data from 37 European hospitals in 14 countries in 2013 (median 3.7 (range: 0.6-18.5) per 10000 patients days) [246]. Variations in CDI rates may also be due to other differences in case ascertainment, both regionally and globally, such as practices and criteria for specimen collection, testing policies and methodologies, under-ascertainment of cases, and reporting requirements [5,246,247]. Efforts to harmonize CDI surveillance protocols within and across countries, such as in Europe, will facilitate the monitoring of epidemiological changes, implementation of infection control protocols $[246,248]$. Our review shows there is a paucity of data on the incidence of CDI from regions other than North America, Europe and the Western Pacific. This gap in the evidence base is noteworthy as there is evidence of high burden of CDI in other world regions [249]. Limited country-specific data may be due to a combination of lower prevalence and C. difficile not being tested commonly in these regions $[250,251]$. Identifying the global transmission of $C$. difficile by molecular characterization is also an important component of surveillance [252] that will further advance our understanding of its associated burden.

Our assessment of rates by age groups shows the importance of age-specific rates to monitor and address the burden of CDI effectively. Our meta-estimates of CDI rates provide evidence for the magnitude of the burden among across age groups and consistently show that elderly populations are disproportionally af- 


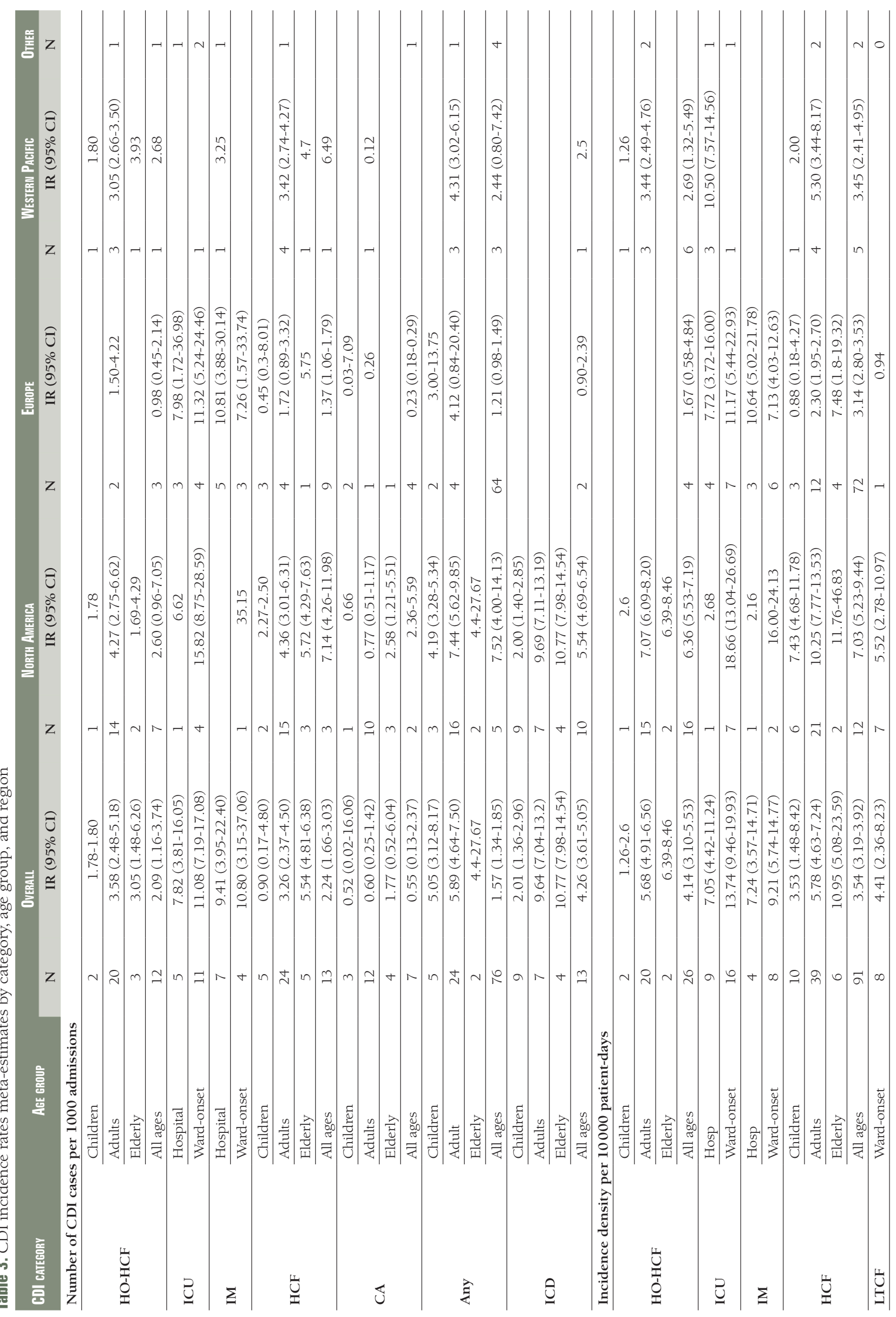




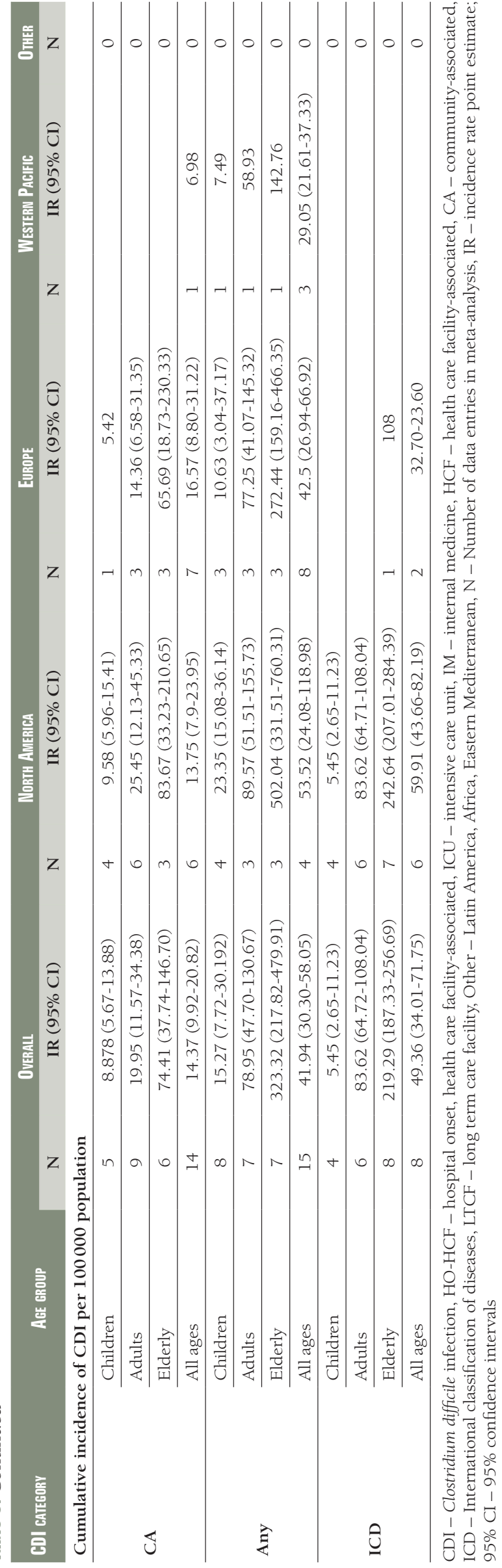

fected by CDI; as incidence rates increase with increasing age [11] and over $80 \%$ of CDI deaths occur in those over 65 years [2]. The high burden of $C$. difficile on older adults may be due to a range of factors including: more frequent interactions with health care systems, higher use of antimicrobials, and physiologic changes such as decreases in immune responses and multi-morbidity [2]. Some risk factors for CDI in the elderly are modifiable, through actions such as antimicrobial stewardship [253] and the targeting of severe and recurrent cases of CDI, which may impact morbidity and outcomes [254]. These approaches are also relevant to cases of CDI in other age groups. Though we found low rates of CDI among the paediatric population, we also identified discrepancies in the inclusion criteria for classifying pediatric CDI cases. There is a high carriage rate of $C$. difficile in neonates. Consequently, C. difficile is often thought to be non-pathogenic in infants and assessing the burden of CDI in this population is more difficult [255]. Further, episodes of disease are often of shorter duration and fewer complications as compared to adults [256]. Considering that increases in the rate of CDI hospitalizations in children have been reported, in North America for instance $[244,257,258]$, and the limited information regarding the burden of CDI, careful assessment of surveillance data among the pediatric population is warranted. It is important that studies adhere to standardized surveillance recommendations (eg, infants should be excluded both from the number of cases and the study population in incidence rate calculations) and that CDI rates are analyzed for key age groups to identify monitor subgroups at risk of disease.

While there is evidence from individual studies that the incidence of CDI in ICU patients is decreasing [37,112], our study showed CDI rates were consistently high in the ICU or IM setting. These high rates may be related to the multiple major risk factors that are often found in critically ill or older hospitalized patients [259]. CDI in the ICU has been associated with an increase in mortality, and increased length of stay compared to other settings $[259,260]$ highlighting the importance for developing strategies and protocols for reducing infection in these settings. Our review also indicates the need for assessments of CDI in nursing homes and other LTCF, where limited data are available currently and the burden is estimated to be high $[222,261,262]$.

The rates of CA-CDI identified through this analysis were generally low, yet, comparable across world regions. Under-ascertainment or under-reporting of CA-CDI may have contributed to the lower rates identified, as well as the lower density of individuals in the community who are at high-risk for CDI. In countries where research has been conducted, such as in the US and the UK, a substantial proportion of CDI cases that are acquired and have symptom onset in the community (20\%-45\% of all CDI are CA-CDI $[1,2,75,263])$. Understanding the burden of CA$\mathrm{CDI}$ is important as these cases may be characterized by different risk factors, with a younger age group, present- 
ing with less severe disease, and with less prior exposure to antimicrobials [121]. Further knowledge of these factors and on the links with health care setting is important to develop strategies for lowering the rate of CDI in these distinct populations.

To our knowledge, this is the largest meta-analysis of CDI incidence data to date obtained data using publications from a 10-year period to identify a substantial amount of data. This comprehensive review allowed us to estimate CDI rates for a range of metrics across settings. Through the exclusion of studies that reported rates from outbreaks, our estimates provide a baseline epidemiological rate of the burden associated with CDI. However, there are limitations to our review and meta-analysis. One limitation is the low number of reports from several countries, preventing a truly global picture of CDI rates. Though this could partially be influenced by our inclusion criteria (peer-reviewed articles in English and Spanish), we added to the global reach of our search by including data from publically available surveillance reports. Other sources of data, beyond the scope of our study, including short bulletins and publications in other languages need to be systematically assessed. We also identified a limited number of reports of CDI for some clinical settings and case definitions (such as LTCF and community), which limits the estimation of the impact of $C$. difficile on these diverse populations. We used data in studies published between 2005 and 2015 to include a wide range of relevant reports. However, rates in the early years of these publications (ranging from 1993 until 2015) may be less representative of the current epidemiology of CDI due to changes in rates over time. In addition, some recent data on CDI incidence from 2015 may have not been included in our estimates because our search criteria might not have captured studies during this year. Finally, results from meta-analyses are impacted by the characteristics of the primary studies, which may include variations in case definitions, testing methods, and case identification. We aimed to limit these variations in this study through our inclusion criteria and analysis, yet, heterogeneity remains.

\section{CONCLUSIONS}

This study provides baseline epidemiological CDI rates and uncertainty ranges for a variety of settings highlighting the high global burden of disease associated with C. difficile. Our results also emphasize the need for the application of standardized surveillance recommendations, the reporting of age-specific incidence rates, and research in countries were sustainable surveillance by national or regional authorities is not possible to obtain a fuller picture of the burden of CDI. Improving surveillance and case ascertainment rates globally is important to characterize, to understand the burden of disease associated with $C$. difficile, and to implement effective prevention and infection control measures.

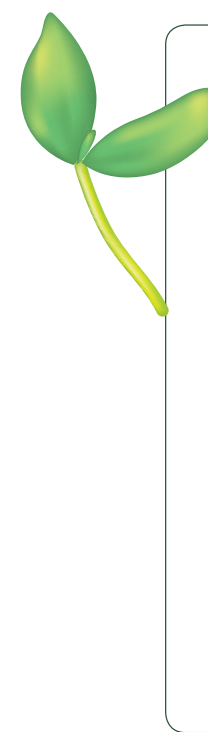

Acknowledgements: We are thankful to University of Edinburgh, Medical Librarian, Ms. Marshall Dozier for her assistance in developing search strategies and to investigators who kindly provided data for meta-analyses. Editorial assistance with the preparation of the manuscript was provided by a professional medical writer, Nicola Truss PhD of inScience Communications, Springer Healthcare, UK.

Funding: This work was supported financially by Sanofi Pasteur.

Authorship contributions: EB, HN, MHK, and HC conceived and designed the study. EB, TS, CL, JB, and IL conducted the study. EB analysed the data. EB, CL, JB, IL, CW, HC, MHK, and HN interpreted the data. EB and MHK wrote the first draft and are accountable for the accuracy and integrity of the contents in the manuscript. All authors provided critical revisions of manuscript for the intellectual content. All authors provided approval of the final draft of manuscript.

Competing interests: MHK is an employee of Sanofi Pasteur. EB, TS, CL, IL, JB, CW have no relevant conflict of interest to declare. HC and HN received grants from Sanofi Pasteur. HC is the Editor-in-Chief of the Journal of Global Health. All authors have completed the ICMJE uniform disclosure form at http://www.icmje.org/coi_ disclosure.pdf (available upon request from the corresponding author), and declare no other conflicts of interest.

\section{Additional material}

Online Supplementary Document 
1 Lessa FC, Gould CV, McDonald LC. Current status of Clostridium difficile infection epidemiology. (Special Issue: Fidaxomicin and the evolving approach to the treatment of Clostridium difficile infection.). Clin Infect Dis. 2012;55:S65-70. Medline:22752867 doi:10.1093/cid/cis319

2 Lessa FC, Mu Y, Bamberg WM, Beldavs ZG, Dumyati GK, Dunn JR, et al. Burden of Clostridium difficile infection in the United States. N Engl J Med. 2015;372:825-34. Medline:25714160 doi:10.1056/NEJMoa1408913

3 Barbut F, Mastrantonio P, Delmee M, Brazier J, Kuijper E, Poxton I, et al. Prospective study of Clostridium difficile infections in Europe with phenotypic and genotypic characterisation of the isolates. Clin Microbiol Infect. 2007;13:1048-57. Medline:17850341 doi:10.1111/j.1469-0691.2007.01824.x

4 Bauer MP, Notermans DW, van Benthem BH, Brazier JS, Wilcox MH, Rupnik M, et al. Clostridium difficile infection in Europe: a hospital-based survey. Lancet. 2011;377:63-73. Medline:21084111 doi:10.1016/S0140-6736(10)61266-4

5 Davies KA, Longshaw CM, Davis GL, Bouza E, Barbut F, Barna Z, et al. Underdiagnosis of Clostridium difficile across Europe: the European, multicentre, prospective, biannual, point-prevalence study of Clostridium difficile infection in hospitalised patients with diarrhoea (EUCLID). Lancet Infect Dis. 2014;14:1208-19. Medline:25455988 doi:10.1016/ S1473-3099(14)70991-0

6 Borren NZ, Ghadermarzi S, Hutfless S, Ananthakrishnan AN. The emergence of Clostridium difficile infection in Asia: A systematic review and meta-analysis of incidence and impact. PLoS One. 2017;12:e0176797. Medline:28463987 doi:10.1371/journal.pone.0176797

7 Bakken JS, Polgreen PM, Beekmann SE, Riedo FX, Streit JA. Treatment approaches including fecal microbiota transplantation for recurrent Clostridium difficile infection (RCDI) among infectious disease physicians. Anaerobe. 2013;24:204. Medline:24012687 doi:10.1016/j.anaerobe.2013.08.007

8 Zhang S, Palazuelos-Munoz S, Balsells EM, Harish N, Chit A, Kyaw MH. Cost of hospital management of Clostridium difficile infection in United States-a meta-analysis and modelling study. BMC Infect Dis. 2016;16:447. Medline:27562241 doi:10.1186/s12879-016-1786-6

9 Cassini A, Plachouras D, Eckmanns T, Abu Sin M, Blank HP, Ducomble T, et al. Burden of Six Healthcare-Associated Infections on European Population Health: Estimating Incidence-Based Disability-Adjusted Life Years through a Population Prevalence-Based Modelling Study. PLoS Med. 2016;13:e1002150. Medline:27755545 doi:10.1371/journal. pmed. 1002150

10 Wiegand PN, Nathwani D, Wilcox MH, Stephens J, Shelbaya A, Haider S. Clinical and economic burden of Clostridium difficile infection in Europe: a systematic review of healthcare-facility-acquired infection. J Hosp Infect. 2012;81:1-14. Medline:22498638 doi:10.1016/j.jhin.2012.02.004

11 Lucado J, Gould C, Elixhauser A; Healthcare Cost and Utilization Project. Clostridium difficile Infection (CDI) in hospital stays, 2009. 2012. Available: http://www.hcup-us.ahrq.gov/reports/statbriefs/sb124.pdf. Accessed: [01 March 2017].

12 Lyytikainen O, Turunen H, Sund R, Rasinpera M, Kononen E, Ruutu P, et al. Hospitalizations and deaths associated with Clostridium difficile infection, Finland, 1996-2004. Emerg Infect Dis. 2009;15:761-5. Medline:19402963 doi:10.3201/ eid1505.081154

13 Chitnis AS, Holzbauer SM, Belflower RM, Winston LG, Bamberg WM, Lyons C, et al. Epidemiology of community-associated Clostridium difficile infection, 2009 through 2011. JAMA Intern Med. 2013;173:1359-67. Medline:23780507 doi:10.1001/jamainternmed.2013.7056

14 European Centre for Disease Prevention and Control. European surveillance of Clostridium difficile infections. Stockholm: ECDC, 2015.

15 McDonald LC, Gerding DN, Johnson S, Bakken JS, Carroll KC, Coffin SE, et al. Clinical Practice Guidelines for Clostridium difficile Infection in Adults and Children: 2017 Update by the Infectious Diseases Society of America (IDSA) and Society for Healthcare Epidemiology of America (SHEA). Clin Infect Dis. 2018;66:987-94. Medline:29562266 doi:10.1093/cid/ciy149

16 Centers for Disease Control and Prevention. The national and state healthcare-associated infections progress report. 2016.

17 Services; TDoHaH. National action plan to prevent health care-associated infections: road map to elimination (HAI Action Plan). 2013.

18 McDonald LC, Coignard B, Dubberke E, Song XY, Horan T, Kutty PK. Recommendations for surveillance of Clostridium difficile-associated disease. Infect Control Hosp Epidemiol. 2007;28:140-5. Medline:17265394 doi:10.1086/511798

19 Ahmetagic S, Salkic N, Ahmetagic A, Custovic A, Tihic N, Smajlovic J, et al. Clostridium difficile infection in hospitalized patients at University Clinical Center Tuzla, Bosnia and Herzegovina: a 4 year experience. Mater Sociomed. 2013;25:1537. Medline:24167425 doi:10.5455/msm.2013.25.153-157

20 Alcala L, Marin M, Martin A, Sanchez-Somolinos M, Catalan P, Pelaez MT, et al. Laboratory diagnosis of Clostridium difficile infection in Spain: a population-based survey. J Hosp Infect. 2011;79:13-7. Medline:21741114 doi:10.1016/j. jhin.2011.05.017

21 Aldeyab MA, Harbarth S, Vernaz N, Kearney MP, Scott MG, Funston C, et al. Quasiexperimental study of the effects of antibiotic use, gastric acid-suppressive agents, and infection control practices on the incidence of Clostridium difficile-associated diarrhea in hospitalized patients. Antimicrob Agents Chemother. 2009;53:2082-8. Medline:19289520 doi:10.1128/AAC.01214-08

22 Al-Eidan FA. Proton pump inhibitors and the increased risk of Clostridium difficile infections: A case-control study. Int J Pharma Bio Sci. 2013;4:B735-41.

23 Alfa MJ, Lo E, Olson N, MacRae M, Buelow-Smith L. Use of a daily disinfectant cleaner instead of a daily cleaner reduced hospital-acquired infection rates. American Journal of Infection Control. 2015;43:141-6 6p. 
24 Al-Tawfiq JA, Abed MS. Clostridium difficile-associated disease among patients in Dhahran, Saudi Arabia. Travel Med Infect Dis. 2010;8:373-6. Medline:21030314 doi:10.1016/j.tmaid.2010.10.003

25 Alvarez-Lerma F, Palomar M, Villasboa A, Amador J, Almirall J, Posada MP, et al. Epidemiological study of Clostridium difficile infection in critical patients admitted to the Intensive Care Unit. Med Intensiva. 2014;38:558-66. Medline:24503331 doi:10.1016/j.medin.2013.11.007

26 Ang CW, Heyes G, Morrison P, Carr B. The acquisition and outcome of ICU-acquired Clostridium difficile infection in a single centre in the UK. J Infect. 2008;57:435-40. Medline:19013649 doi:10.1016/j.jinf.2008.10.002

27 Argamany JR, Aitken SL, Lee GC, Boyd NK, Reveles KR. Regional and seasonal variation in Clostridium difficile infections among hospitalized patients in the United States, 2001-2010. Am J Infect Control. 2015;43:435-40. Medline:25952045 doi:10.1016/j.ajic.2014.11.018

28 Armbruster S, Goldkind L. A 5-year retrospective review of experience with Clostridium difficile-associated diarrhea. Mil Med. 2012;177:456-9. Medline:22594138 doi:10.7205/MILMED-D-11-00389

29 Babey K, Kelton S, Milne WK, Muileboom J, Voth B, Kelly L, et al. Clostridium difficile infection in rural Ontario: a retrospective multisite population-based study. Can J Rural Med. 2015;20:117-20. Medline:26447730

30 Balihar K, Kozak F, Kozeluhova J, Hejda V, Fremundova L, Krcma M, et al. Clostridium difficile infection in hospitalized patients at a Czech tertiary center: analysis of epidemiology, clinical features, and risk factors of fulminant course. Eur J Gastroenterol Hepatol. 2014;26:880-7. Medline:24942955 doi:10.1097/MEG.0000000000000139

31 Barbut F, Gariazzo B, Bonne L, Lalande V, Burghoffer B, Luiuz R, et al. Clinical features of Clostridium difficile-associated infections and molecular characterization of strains: results of a retrospective study, 2000-2004. Infect Control Hosp Epidemiol. 2007;28:131-9. Medline:17265393 doi:10.1086/511794

32 Barletta JF, Sclar DA. Proton pump inhibitors increase the risk for hospital-acquired Clostridium difficile infection in critically ill patients. Crit Care. 2014;18:714. Medline:25540023 doi:10.1186/s13054-014-0714-7

33 Bengualid V, Umesh KC, Alapati J, Berger J. Clostridium difficile at a community hospital in the Bronx, New York: incidence prevalence and risk factors from 2006 to 2008. Am J Infect Control. 2011;39:183-7. Medline:21458681 doi:10.1016/j.ajic.2010.10.027

34 Benoit SR, McDonald LC, English R, Tokars JI. Automated surveillance of Clostridium difficile infections using BioSense. Infect Control Hosp Epidemiol. 2011;32:26-33. Medline:21128815 doi:10.1086/657633

35 Benson L, Song X, Campos J, Singh N. Changing epidemiology of Clostridium difficile-associated disease in children. Infect Control Hosp Epidemiol. 2007;28:1233-5. Medline:17926272 doi:10.1086/520732

36 Bishara J, Farah R, Mograbi J, Khalaila W, Abu-Elheja O, Mahamid M, et al. Obesity as a risk factor for Clostridium difficile infection. Clin Infect Dis. 2013;57:489-93. Medline:23645850 doi:10.1093/cid/cit280

37 Bouza E, Rodríguez-Créixems M, Alcalá L, Marín M, De Egea V, Braojos F, et al. Is Clostridium difficile infection an increasingly common severe disease in adult intensive care units? A 10-year experience. Journal of Critical Care. 2015;30:543-9 7p.

38 Brakovich B, Bonham E, VanBrackle L. War on the spore: Clostridium difficile disease among patients in a long-term acute care hospital. J Healthc Qual. 2013;35:15-21. Medline:22304334 doi:10.1111/j.1945-1474.2011.00182.x

39 Brown K, Valenta K, Fisman D, Simor A, Daneman N. Hospital ward antibiotic prescribing and the risks of Clostridium difficile infection. JAMA Intern Med. 2015;175:626-33. Medline:25705994 doi:10.1001/jamainternmed.2014.8273

40 Buendgens L, Bruensing J, Matthes M, Duckers H, Luedde T, Trautwein C, et al. Administration of proton pump inhibitors in critically ill medical patients is associated with increased risk of developing Clostridium difficile-associated diarrhea. J Crit Care. 2014;29:696.e11. Medline:24674763 doi:10.1016/j.jcrc.2014.03.002

41 Camacho-Ortiz A, Galindo-Fraga A, Rancel-Cordero A, Macias AE, Lamothe-Molina P, Ponce de Leon-Garduno A, et al. Factors associated with Clostridium difficile disease in a tertiary-care medical institution in Mexico: a case-control study. Rev Invest Clin. 2009;61:371-7. Medline:20184096

42 Campbell RJ, Giljahn L, Machesky K, Cibulskas-White K, Lane LM, Porter K, et al. Clostridium difficile infection in Ohio hospitals and nursing homes during 2006. Infect Control Hosp Epidemiol. 2009;30:526-33. Medline:19419272 doi:10.1086/597507

43 Catanzaro M, Cirone J. Real-time polymerase chain reaction testing for Clostridium difficile reduces isolation time and improves patient management in a small community hospital. Am J Infect Control. 2012;40:663-6. Medline:22153847 doi:10.1016/j.ajic.2011.09.005

44 Centers for Disease C. Prevention. Severe Clostridium difficile-associated disease in populations previously at low riskfour states, 2005. MMWR Morb Mortal Wkly Rep. 2005;54:1201-5. Medline:16319813

45 Centers for Disease C. Prevention. Surveillance for community-associated Clostridium difficile-Connecticut, 2006. MMWR Morb Mortal Wkly Rep. 2008;57:340-3. Medline:18385641

46 Chan M, Lim P, Chow A, Win M, Barkham TM. Surveillance for Clostridium difficile infection: ICD-9 coding has poor sensitivity compared to laboratory diagnosis in hospital patients, Singapore. PLoS One. 2011;6:e15603. Medline:21283751 doi:10.1371/journal.pone.0015603

47 Chandler RE, Hedberg K, Cieslak PR. Clostridium difficile-associated disease in Oregon: increasing incidence and hospital-level risk factors. Infect Control Hosp Epidemiol. 2007;28:116-22. Medline:17265391 doi:10.1086/511795

48 Chen KT, Stephens DJ, Anderson E, Acton R, Saltzman D, Hess DJ. Clostridium difficile infection in the pediatric surgery population. J Pediatr Surg. 2012;47:1385-9. Medline:22813801 doi:10.1016/j.jpedsurg.2011.12.001

49 Cheng VCC, Yam WC, Lam OTC, Tsang JLY, Tse EYF, Siu GKH, et al. Clostridium difficile isolates with increased sporulation: emergence of PCR ribotype 002 in Hong Kong. Eur J Clin Microbiol Infect Dis. 2011;30:1371-81. Medline:21468685 doi:10.1007/s10096-011-1231-0 
50 Chopra T, Neelakanta A, Dombecki C, Awali RA, Sharma S, Kaye KS, et al. Burden of Clostridium difficile infection on hospital readmissions and its potential impact under the Hospital Readmission Reduction Program. Am J Infect Control. 2015;43:314-7. Medline:25838133 doi:10.1016/j.ajic.2014.11.004

51 Chung CH, Wu CJ, Lee HC, Yan JJ, Chang CM, Lee NY, et al. Clostridium difficile infection at a medical center in southern Taiwan: incidence, clinical features and prognosis. J Microbiol Immunol Infect. 2010;43:119-25. Medline:20457428 doi:10.1016/S1684-1182(10)60019-9

52 Cloud J, Noddin L, Pressman A, Hu M, Kelly C. Clostridium difficile strain NAP-1 is not associated with severe disease in a nonepidemic setting. Clin Gastroenterol Hepatol. 2009;7:868-73.e2. Medline:19465153 doi:10.1016/j.cgh.2009.05.018

53 Collins CE, Ayturk MD, Flahive JM, Emhoff TA, Anderson FA Jr, Santry HP. Epidemiology and outcomes of community-acquired Clostridium difficile infections in Medicare beneficiaries. J Am Coll Surg. 2014;218:1141-7.e1. Medline:24755188 doi:10.1016/j.jamcollsurg.2014.01.053

54 Cooper PB, Heuer AJ, Warren CA. Electronic screening of patients for predisposition to Clostridium difficile infection in a community hospital. Am J Infect Control. 2013;41:232-5. Medline:22990298 doi:10.1016/j.ajic.2012.03.022

55 Czepiel J, Kedzierska J, Biesiada G, Birczynska M, Perucki W, Nowak P, et al. Epidemiology of Clostridium difficile infection: results of a hospital-based study in Krakow, Poland. Epidemiol Infect. 2015;143:3235-43. Medline:25858553 doi:10.1017/S0950268815000552

56 Daneman N, Stukel TA, Ma X, Vermeulen M, Guttmann A. Reduction in Clostridium difficile infection rates after mandatory hospital public reporting: findings from a longitudinal cohort study in Canada. PLoS Medicine. 2012;9:e1001268.

57 Di Bella S, Musso M, Cataldo MA, Meledandri M, Bordi E, Capozzi D, et al. Clostridium difficile infection in Italian urban hospitals: data from 2006 through 2011. BMC Infect Dis. 2013;13:146. Medline:23522431 doi:10.1186/14712334-13-146

58 Dial S, Delaney JA, Barkun AN, Suissa S. Use of gastric acid-suppressive agents and the risk of community-acquired Clostridium difficile-associated disease. JAMA. 2005;294:2989-95. Medline:16414946 doi:10.1001/jama.294.23.2989

59 Dial S, Kezouh A, Dascal A, Barkun A, Suissa S. Patterns of antibiotic use and risk of hospital admission because of Clostridium difficile infection. CMAJ. 2008;179:767-72. Medline:18838451 doi:10.1503/cmaj.071812

60 DiDiodato $G$. Has improved hand hygiene compliance reduced the risk of hospital-acquired infections among hospitalized patients in Ontario? Analysis of publicly reported patient safety data from 2008 to 2011. Infect Control Hosp Epidemiol. 2013;34:605-10. Medline:23651891 doi:10.1086/670637

61 Dodek PM, Norena M, Ayas NT, Romney M, Wong H. Length of stay and mortality due to Clostridium difficile infection acquired in the intensive care unit. J Crit Care. 2013;28:335-40. Medline:23337482 doi:10.1016/j.jcrc.2012.11.008

62 Drudy D, Harnedy N, Fanning S, O’Mahony R, Kyne L. Isolation and characterisation of toxin A-negative, toxin B-positive Clostridium difficile in Dublin, Ireland. Clin Microbiol Infect. 2007;13:298-304. Medline:17391385 doi:10.1111/ j.1469-0691.2006.01634.x

63 Dubberke ER, Butler AM, Yokoe DS, Mayer J, Hota B, Mangino JE, et al. Multicenter study of Clostridium difficile infection rates from 2000 to 2006. Infect Control Hosp Epidemiol. 2010;31:1030-7. Medline:20695799 doi:10.1086/656245

64 Dubberke ER, McMullen KM, Mayfield JL, Reske KA, Georgantopoulos P, Warren DK, et al. Hospital-associated Clostridium difficile infection: is it necessary to track community-onset disease? Infect Control Hosp Epidemiol. 2009;30:332-7. Medline:19239377 doi:10.1086/596604

65 Dubberke ER, Reske KA, McDonald LC, Fraser VJ. ICD-9 codes and surveillance for Clostridium difficile-associated disease. Emerg Infect Dis. 2006;12:1576-9. Medline:17176576 doi:10.3201/eid1210.060016

66 Duleba K, Pawlowska M, Wietlicka-Piszcz M. Clostridium difficile infection in children hospitalized due to diarrhea. Eur J Clin Microbiol Infect Dis. 2014;33:201-9. Medline:24213847 doi:10.1007/s10096-013-1946-1

67 Durkin MJ, Baker AW, Dicks KV, Lewis SS, Chen LF, Anderson DJ, et al. A comparison between National Healthcare Safety Network laboratory-identified event reporting versus traditional surveillance for Clostridium difficile infection. Infect Control Hosp Epidemiol. 2015;36:125-31. Medline:25632994 doi:10.1017/ice.2014.42

68 Eckert C, Coignard B, Hebert M, Tarnaud C, Tessier C, Lemire A, et al. Clinical and microbiological features of Clostridium difficile infections in France: the ICD-RAISIN 2009 national survey. Med Mal Infect. 2013;43:67-74. Medline:23498135 doi:10.1016/j.medmal.2013.01.004

69 Elixhauser A, Jhung MA; Healthcare Cost and Utilization Project. Clostridium difficile-associated disease in U.S. hospitals, 1993. Statistical Brief. 2005;50:2008.

70 Elligsen M, Walker SA, Pinto R, Simor A, Mubareka S, Rachlis A, et al. Audit and feedback to reduce broad-spectrum antibiotic use among intensive care unit patients: a controlled interrupted time series analysis. Infect Control Hosp Epidemiol. 2012;33:354-61. Medline:22418630 doi:10.1086/664757

71 Ergen EK, Akalin H, Yilmaz E, Sinirtas M, Alver O, Heper Y, et al. Nosocomial diarrhea and Clostridium Difficile associated diarrhea in a Turkish University Hospital. Med Mal Infect. 2009;39:382-7. Medline:19269761 doi:10.1016/j. medmal.2009.02.001

72 Evans ME, Simbartl LA, Kralovic SM, Jain R, Roselle GA. Clostridium difficile infections in Veterans Health Administration acute care facilities. Infect Control Hosp Epidemiol. 2014;35:1037-42. Medline:25026621 doi:10.1086/677151

73 Faires MC, Pearl DL, Ciccotelli WA, Berke O, Reid-Smith RJ, Weese JS. Detection of Clostridium difficile infection clusters, using the temporal scan statistic, in a community hospital in southern Ontario, Canada, 2006-2011. BMC Infect Dis. 2014;14:254. Medline:24885351 doi:10.1186/1471-2334-14-254

74 Fashner J, Ribble L, Garcia M. Clostridium difficile-associated diarrhea at a community hospital: Ten-year analysis of infection rates and the relationship with proton pump inhibitor use. Hosp Pharm. 2012;47:446-50. doi:10.1310/hpj4706-446 
75 Fellmeth G, Yarlagadda S, Iyer S. Epidemiology of community-onset Clostridium difficile infection in a community in the South of England. J Infect Public Health. 2010;3:118-23. Medline:20869672 doi:10.1016/j.jiph.2010.07.002

76 Fenner L, Frei R, Gregory M, Dangel M, Stranden A, Widmer AF. Epidemiology of Clostridium difficile-associated disease at University Hospital Basel including molecular characterisation of the isolates 2006-2007. Eur J Clin Microbiol Infect Dis. 2008;27:1201-7. Medline:18560909 doi:10.1007/s10096-008-0564-9

77 Ferguson JK, Cheng AC, Gilbert GL, Gottlieb T, Korman T, McGregor A, et al. Clostridium difficile laboratory testing in Australia and New Zealand: national survey results and Australasian Society for Infectious Diseases recommendations for best practice. Pathology. 2011;43:482-7. Medline:21716158 doi:10.1097/PAT.0b013e328348c9b4

78 Folkhälsomyndigheten. Clostridium difficile írsrapport 2014. 2015. Available: https://www.folkhalsomyndigheten.se/ pagefiles/20544/Clostridium-difficile-arsrapport-2014-15028.pdf. Accessed: [March 2017].

79 Foster NF, Collins DA, Ditchburn SL, Duncan CN, van Schalkwyk JW, Golledge CL, et al. Epidemiology of Clostridium difficile infection in two tertiary-care hospitals in Perth, Western Australia: A cross-sectional study. New Microbes New Infect. 2014;2:64-71. Medline:25356346 doi:10.1002/nmi2.43

80 Garcia C, Samalvides F, Vidal M, Gotuzzo E, Dupont HL. Epidemiology of Clostridium difficile-associated diarrhea in a Peruvian tertiary care hospital. Am J Trop Med Hyg. 2007;77:802-5. Medline:17984329 doi:10.4269/ajtmh.2007.77.802

81 Gase KA, Haley VB, Xiong K, Van Antwerpen C, Stricof RL. Comparison of 2 Clostridium difficile surveillance methods: National Healthcare Safety Network's laboratory-identified event reporting module versus clinical infection surveillance. Infect Control Hosp Epidemiol. 2013;34:284-90. Medline:23388363 doi:10.1086/669509

82 Gastmeier P, Weitzel-Kage D, Behnke M, Eckmanns T. Surveillance of Clostridium difficile-associated diarrhoea with the German nosocomial infection surveillance system KISS (CDAD-KISS). Int J Antimicrob Agents. 2009;33 Suppl 1:S19- 23. Medline:19303563 doi:10.1016/S0924-8579(09)70011-1

83 Gilca R, Hubert B, Fortin E, Gaulin C, Dionne M. Epidemiological patterns and hospital characteristics associated with increased incidence of Clostridium difficile infection in Quebec, Canada, 1998-2006. Infect Control Hosp Epidemiol. 2010;31:939-47. Medline:20677973 doi:10.1086/655463

84 Goorhuis A, Legaria MC, van den Berg RJ, Harmanus C, Klaassen CH, Brazier JS, et al. Application of multiple-locus variable-number tandem-repeat analysis to determine clonal spread of toxin A-negative Clostridium difficile in a general hospital in Buenos Aires, Argentina. Clin Microbiol Infect. 2009;15:1080-6. Medline:19438624 doi:10.1111/j.14690691.2009.02759.x

85 Gordin FM, Schultz ME, Huber RA, Gill JA. Reduction in nosocomial transmission of drug-resistant bacteria after introduction of an alcohol-based handrub. Infection Control \& Hospital Epidemiology. 2005;26:650-3 4p.

86 Gravel D, Miller M, Simor A, Taylor G, Gardam M, McGeer A, et al. Health care-associated Clostridium difficile infection in adults admitted to acute care hospitals in Canada: a Canadian Nosocomial Infection Surveillance Program Study. Clin Infect Dis. 2009;48:568-76. Medline:19191641 doi:10.1086/596703

87 Gutierrez RL, Riddle MS, Porter CK. Epidemiology of Clostridium difficile infection among active duty United States military personnel (1998-2010). BMC Infect Dis. 2013;13:609. Medline:24373384 doi:10.1186/1471-2334-13-609

88 Gweon TG, Choi M, Baeg M, Lim C, Park J, Lee I, et al. Hematologic diseases: high risk of Clostridium difficile associated diarrhea. World J Gastroenterol. 2014;20:6602-7. Medline:24914383 doi:10.3748/wjg.v20.i21.6602

89 Haas JP, Menz J, Dusza S, Montecalvo MA. Implementation and impact of ultraviolet environmental disinfection in an acute care setting. Am J Infect Control. 2014;42:586-90. Medline:24837107 doi:10.1016/j.ajic.2013.12.013

90 Halabi WJ, Nguyen VQ, Carmichael JC, Pigazzi A, Stamos MJ, Mills S. Clostridium difficile colitis in the United States: a decade of trends, outcomes, risk factors for colectomy, and mortality after colectomy. J Am Coll Surg. 2013;217:80212. Medline:24011436 doi:10.1016/j.jamcollsurg.2013.05.028

91 Haley VB, DiRienzo AG, Lutterloh EC, Stricof RL. Quantifying sources of bias in National Healthcare Safety Network laboratory-identified Clostridium difficile infection rates. Infect Control Hosp Epidemiol. 2014;35:1-7. Medline:24334790 doi:10.1086/674389

92 Hamel M, Zoutman D, O'Callaghan C. Exposure to hospital roommates as a risk factor for health care-associated infection. Am J Infect Control. 2010;38:173-81. Medline:20022405 doi:10.1016/j.ajic.2009.08.016

93 Han SH, Kim H, Lee K, Jeong SJ, Park KH, Song JY, et al. Epidemiology and clinical features of toxigenic culture-confirmed hospital-onset Clostridium difficile infection: a multicentre prospective study in tertiary hospitals of South Korea. J Med Microbiol. 2014;63:1542-51. Medline:25187603 doi:10.1099/jmm.0.070672-0

94 Han Z, McMullen KM, Russo AJ, Copper SM, Warren DK, Dubberke ER. A Clostridium difficile infection "intervention": change in toxin assay results in fewer C. difficile infection cases without changes in patient outcomes. Am J Infect Control. 2012;40:349-53. Medline:21794950 doi:10.1016/j.ajic.2011.04.002

95 Harbrecht BG, Franklin GA, Shirley RM, Smith JW, Miller FB, Richardson JD. Statewide experience with Clostridium difficile colitis in academic and non-academic medical centers. Surg Infect (Larchmt). 2012;13:88-92. Medline:21028991 doi:10.1089/sur.2009.033

96 Hensgens MP, Goorhuis A, Dekkers OM, van Benthem BH, Kuijper EJ. All-cause and disease-specific mortality in hospitalized patients with Clostridium difficile infection: a multicenter cohort study. Clin Infect Dis. 2013;56:1108-16. Medline:23300235 doi:10.1093/cid/cis1209

97 Hensgens MPM, Dekkers OM, Demeulemeester A, Buiting AGM, Bloembergen P, Benthem BHB, et al. Diarrhoea in general practice: when should a Clostridium difficile infection be considered? Results of a nested case-control study. Clin Microbiol Infect. 2014;20:O1067-74. Medline:25040463 doi:10.1111/1469-0691.12758

98 Hikone M, Ainoda Y, Tago S, Fujita T, Hirai Y, Takeuchi K, et al. Risk factors for recurrent hospital-acquired Clostridium difficile infection in a Japanese university hospital. Clin Exp Gastroenterol. 2015;8:191-6. Medline:26203270 
99 Honda H, Yamazaki A, Sato Y, Dubberke ER. Incidence and mortality associated with Clostridium difficile infection at a Japanese tertiary care center. Anaerobe. 2014;25:5-10. Medline:24184291 doi:10.1016/j.anaerobe.2013.10.004

100 Hooker EA, Bochan M, Reiff TT, Blackwell C, Webb KW, Hart KW. Decreasing Clostridium difficile health care-associated infections through use of a launderable mattress cover. Am J Infect Control. 2015;43:1326-30. Medline:26498703 doi:10.1016/j.ajic.2015.07.002

101 Howell MD, Novack V, Grgurich P, Soulliard D, Novack L, Pencina M, et al. Iatrogenic gastric acid suppression and the risk of nosocomial Clostridium difficile infection. Arch Intern Med. 2010;170:784-90. Medline:20458086 doi:10.1001/ archinternmed.2010.89

102 Health Protection Scotland. Commentary on quarterly epidemiological data on Clostridium difficile infection (CDI) and Staphylococcus aureus bacteraemias (SAB) in Scotland. April to June (Q2) 2015. 2015. Available: http://www.hps. scot.nhs.uk/haiic/sshaip/resourcedetail.aspx?id=1690. Accessed: [01 March 2017].

103 Health Protection Surveillance Centre. Annual Epidemiological Reports. 2012-15. Available: http://www.hpsc.ie/az/gastroenteric/clostridiumdifficile/surveillance/notifiablesurveillance/annualreports/. Accessed: [03 March 2017].

104 Health \& Social Care Public Health Agency Northern Ireland. Clostridium difficile surveillance. 2010-15. Available: http://www.publichealth.hscni.net. Accessed: [01 March 2017].

105 Hsu MS, Wang JT, Huang WK, Liu YC, Chang SC. Prevalence and clinical features of Clostridium difficile-associated diarrhea in a tertiary hospital in northern Taiwan. J Microbiol Immunol Infect. 2006;39:242-8. Medline:16783456

106 Institute Scientifique de Sante Publique Belgium. Neely F, Catry B, Lambert M-L. Epidemiology of Clostridium difficile infection in Belgium 2015. Available: http://www.nsih.be/download/CDIF/CDIF-AR-2015-EN.pdf. Accessed: [03 March 2017].

107 Ivanova K, Petrov P, Asseva G, Dobreva E, Ivanov I, Vatcheva-Dobrevska R, et al. Prevalence of Clostridium difficile PCR ribotypes in Bulgaria 2008-2010. Dokl Bulg Akad Nauk. 2011;64:1051-8.

108 Jayatilaka S, Shakov R, Eddi R, Bakaj G, Baddoura WJ, DeBari VA. Clostridium difficile infection in an urban medical center: five-year analysis of infection rates among adult admissions and association with the use of proton pump inhibitors. Ann Clin Lab Sci. 2007;37:241-7. Medline:17709687

109 Jen MH, Saxena S, Bottle A, Pollok R, Holmes A, Aylin P. Assessment of administrative data for evaluating the shifting acquisition of Clostridium difficile infection in England. Journal of Hospital Infection. 2012;80:229-37 9p.

110 Jiang Y, Viner-Brown S, Baier R. Burden of hospital-onset Clostridium difficile infection in patients discharged from Rhode Island hospitals, 2010-2011: application of present on admission indicators. Infect Control Hosp Epidemiol. 2013;34:700-8. Medline:23739074 doi:10.1086/670993

111 Jones G, Taright N, Boelle PY, Marty J, Lalande V, Eckert C, et al. Accuracy of ICD-10 codes for surveillance of Clostridium difficile infections, France. Emerg Infect Dis. 2012;18:979-81. Medline:22607707 doi:10.3201/eid1806.111188

112 Kanamori H, Weber DJ, DiBiase LM, Sickbert-Bennett EE, Brooks R, Teal L, et al. Longitudinal trends in all healthcare-associated infections through comprehensive hospital-wide surveillance and infection control measures over the past 12 years: substantial burden of healthcare-associated infections outside of intensive care units and "other" types of infection. Infect Control Hosp Epidemiol. 2015;36:1139-47. Medline:26108686 doi:10.1017/ice.2015.142

113 Kanerva M, Mentula S, Virolainen-Julkunen A, Karki T, Mottonen T, Lyytikainen O, et al. Reduction in Clostridium difficile infections in Finland, 2008-2010. J Hosp Infect. 2013;83:127-31. Medline:23201398 doi:10.1016/j. jhin.2012.09.021

114 Kang J, Sickbert-Bennett EE, Brown VM, Weber DJ, Rutala WA. Changes in the incidence of health care-associated pathogens at a university hospital from 2005 to 2011. Am J Infect Control. 2014;42:770-5. Medline:24775560 doi:10.1016/j.ajic.2014.03.019

115 Kassavin DS, Pham D, Pascarella L, Yen-Hong K, Goldfarb MA. The combined use of proton pump inhibitors and antibiotics as risk factors for Clostridium difficile infection. Healthc Infect. 2013;18:76-9. doi:10.1071/HI12039

116 Kazakova SV, Ware K, Baughman B, Bilukha O, Paradis A, Sears S, et al. A hospital outbreak of diarrhea due to an emerging epidemic strain of Clostridium difficile. Arch Intern Med. 2006;166:2518-24. Medline:17159019 doi:10.1001/ archinte.166.22.2518

117 Khan FY, Abu-Khattab M, Anand D, Baager K, Alaini A, Siddique MA, et al. Epidemiological features of Clostridium difficile infection among inpatients at Hamad General Hospital in the state of Qatar, 2006-2009. Travel Med Infect Dis. 2012;10:179-85. Medline:22800937 doi:10.1016/j.tmaid.2012.06.004

118 Khanafer N, Blais L, Barbut F, Hirschel B, Vanhems P. Treatment of Clostridium difficile infection in a French university hospital. Scand J Gastroenterol. 2015;50:1253-60. Medline:25877477 doi:10.3109/00365521.2015.1033746

119 Khanafer N, Toure A, Chambrier C, Cour M, Reverdy ME, Argaud L, et al. Predictors of Clostridium difficile infection severity in patients hospitalised in medical intensive care. World J Gastroenterol. 2013;19:8034-41. Medline:24307797 doi:10.3748/wjg.v19.i44.8034

120 Khanna S, Baddour LM, Huskins WC, Kammer PP, Faubion WA, Zinsmeister AR, et al. The epidemiology of Clostridium difficile infection in children: a population-based study. Clin Infect Dis. 2013;56:1401-6. Medline:23408679 doi:10.1093/cid/cit075

121 Khanna S, Pardi DS, Aronson SL, Kammer PP, Orenstein R, St Sauver JL, et al. The epidemiology of community-acquired Clostridium difficile infection: a population-based study. [Erratum appears in Am J Gastroenterol. 2012 Jan;107(1): 150]. Am J Gastroenterol. 2013;107:89-95. Medline:22108454 doi:10.1038/ajg.2011.398

122 Kim J, Kang JO, Kim H, Seo MR, Choi TY, Pai H, et al. Epidemiology of Clostridium difficile infections in a tertiary-care hospital in Korea. Clin Microbiol Infect. 2012;19:521-7. Medline:22712697 doi:10.1111/j.1469-0691.2012.03910.x 
123 Kim J, Smathers SA, Prasad P, Leckerman KH, Coffin S, Zaoutis T. Epidemiological features of Clostridium difficile-associated disease among inpatients at children's hospitals in the United States, 2001-2006. Pediatrics. 2008;122:126670. Medline:19047244 doi:10.1542/peds.2008-0469

124 Kim JH, Toy D, Muder RR. Clostridium difficile infection in a long-term care facility: hospital-associated illness compared with long-term care-associated illness. Infect Control Hosp Epidemiol. 2011;32:656-60. Medline:21666395 doi: $10.1086 / 660767$

125 Kim YS, Han DS, Kim YH, Kim WH, Kim JS, Kim HS, et al. Incidence and clinical features of Clostridium difficile infection in Korea: a nationwide study. Epidemiol Infect. 2013;141:189-94. Medline:22717061 doi:10.1017/ S0950268812000581

126 King RN, Lager SL. Incidence of Clostridium difficile infections in patients receiving antimicrobial and acid-suppression therapy. Pharmacotherapy. 2011;31:642-8. Medline:21923450 doi:10.1592/phco.31.7.642

127 KISS Hospital Infection Surveillance System. Module CDAD-KISS Reference Data. 2015. Available: http://www.nrz-hygiene.de/en/surveillance/hospital-infection-surveillance-system/cdad-kiss/. Accessed: [01 March 2017].

128 Knight N, Strait T, Anthony N, Lovell R, Norton HJ, Sautter R, et al. Clostridium difficile colitis: a retrospective study of incidence and severity before and after institution of an alcohol-based hand rub policy. Am J Infect Control. 2010;38:523-8. Medline:20392538 doi:10.1016/j.ajic.2009.12.008

129 Koh TH, Tan AL, Tan ML, Wang G, Song KP. Epidemiology of Clostridium difficile infection in a large teaching hospital in Singapore. Pathology. 2007;39:438-42. Medline:17676487 doi:10.1080/00313020701444507

130 Kohler P, Bregenzer-Witteck A, Rafeiner P, Schlegel M. Presumably hospital-transmitted Clostridium difficile infections based on epidemiological linkage. Swiss Med Wkly. 2013;143:w13824. Medline:23888435

131 Koo HL, Van JN, Zhao M, Ye X, Revell PA, Jiang ZD, et al. Real-time polymerase chain reaction detection of asymptomatic Clostridium difficile colonization and rising C. difficile-associated disease rates. Infect Control Hosp Epidemiol. 2014;35:667-73. Medline:24799643 doi:10.1086/676433

132 van der Kooi TI, Koningstein M, Lindemans A, Notermans DW, Kuijper E, van den Berg R, et al. Antibiotic use and other risk factors at hospital level for outbreaks with Clostridium difficile PCR ribotype 027. J Med Microbiol. 2008;57:70916. Medline:18480327 doi:10.1099/jmm.0.47711-0

133 Kotila SM, Virolainen A, Snellman M, Ibrahem S, Jalava J, Lyytikainen O. Incidence, case fatality and genotypes causing Clostridium difficile infections, Finland, 2008. Clin Microbiol Infect. 2011;17:888-93. Medline:20874814 doi:10.1111/ j.1469-0691.2010.03384.x

134 Kuntz JL, Chrischilles EA, Pendergast JF, Herwaldt LA, Polgreen PM. Incidence of and risk factors for community-associated Clostridium difficile infection: a nested case-control study. BMC Infect Dis. 2011;11:194. Medline:21762504 doi:10.1186/1471-2334-11-194

135 Kuntz JL, Johnson ES, Raebel MA, Petrik AF, Yang X, Thorp ML, et al. Clostridium difficile infection, Colorado and the northwestern United States, 2007. Emerg Infect Dis. 2012;18:960-2. Medline:22608207 doi:10.3201/eid1806.111528

136 Kuntz JL, Polgreen PM. The importance of considering different healthcare settings when estimating the burden of Clostridium difficile. Clin Infect Dis. 2015;60:831-6. Medline:25477426 doi:10.1093/cid/ciu955

137 Kurti Z, Lovasz BD, Mandel MD, Csima Z, Golovics PA, Csako BD, et al. Burden of Clostridium difficile infection between 2010 and 2013: trends and outcomes from an academic center in Eastern Europe. World J Gastroenterol. 2015;21:6728-35. Medline:26074711 doi:10.3748/wjg.v21.i21.6728

138 Kutty PK, Benoit SR, Woods CW, Sena AC, Naggie S, Frederick J, et al. Assessment of Clostridium difficile-associated disease surveillance definitions, North Carolina, 2005. Infect Control Hosp Epidemiol. 2008;29:197-202. Medline:18241032 doi:10.1086/528813

139 Kutty PK, Woods CW, Sena AC, Benoit SR, Naggie S, Frederick J, et al. Risk factors for and estimated incidence of community-associated Clostridium difficile infection, North Carolina, USA. Emerg Infect Dis. 2010;16:197-204. Medline:20113547 doi:10.3201/eid1602.090953

140 Laffan AM, Bellantoni MF, Greenough WB III, Zenilman JM. Burden of Clostridium difficile-associated diarrhea in a long-term care facility. J Am Geriatr Soc. 2006;54:1068-73. Medline:16866677 doi:10.1111/j.1532-5415.2006.00768.x

141 Lambert PJ, Dyck M, Thompson LH, Hammond GW. Population-based surveillance of Clostridium difficile infection in Manitoba, Canada, by using interim surveillance definitions. Infect Control Hosp Epidemiol. 2009;30:945-51. Medline: 19732008 doi:10.1086/605719

142 Lawrence SJ, Puzniak LA, Shadel BN, Gillespie KN, Kollef MH, Mundy LM. Clostridium difficile in the intensive care unit: epidemiology, costs, and colonization pressure. Infect Control Hosp Epidemiol. 2007;28:123-30. Medline:17265392 doi:10.1086/511793

143 Laza R, Jurac R, Crisan A, Lazureanu V, Licker M, Popovici ED, et al. Clostridium difficile in western Romania: unfavourable outcome predictors in a hospital for infectious diseases. BMC Infect Dis. 2015;15:141. Medline:25881288 doi:10.1186/s12879-015-0895-y

144 Lee J, Tashjian DB, Moriarty KP. Is partial colectomy the operation of choice in pediatric Clostridium difficile colitis? Pediatr Surg Int. 2012;28:603-7. Medline:22543511 doi:10.1007/s00383-012-3097-3

145 Lee TC, Frenette C, Jayaraman D, Green L, Pilote L. Antibiotic self-stewardship: trainee-led structured antibiotic timeouts to improve antimicrobial use. Ann Intern Med. 2014;161:S53-8. Medline:25402404 doi:10.7326/M13-3016

146 Lee YC, Wang JT, Chen AC, Sheng WH, Chang SC, Chen YC. Changing incidence and clinical manifestations of Clostridium difficile-associated diarrhea detected by combination of glutamate dehydrogenase and toxin assay in Northern Taiwan. J Microbiol Immunol Infect. 2012;45:287-95. Medline:22209696 doi:10.1016/j.jmii.2011.12.001 
147 Lessa FC, Mu Y, Winston LG, Dumyati GK, Farley MM, Beldavs ZG, et al. Determinants of Clostridium difficile Infection Incidence Across Diverse United States Geographic Locations. Open Forum Infect Dis. 2014;1:ofu048. -ofu. Medline:25734120 doi:10.1093/ofid/ofu048

148 Lipp MJ, Nero DC, Callahan MA. Impact of hospital-acquired Clostridium difficile. J Gastroenterol Hepatol. 2012;27:1733-7. Medline:22849881 doi:10.1111/j.1440-1746.2012.07242.x

149 Longtin Y, Trottier S, Brochu G, Paquet-Bolduc B, Garenc C, Loungnarath V, et al. Impact of the type of diagnostic assay on Clostridium difficile infection and complication rates in a mandatory reporting program. Clin Infect Dis. 2013;56:6773. Medline:23011147 doi:10.1093/cid/cis840

150 Mah ND, Ahern JW, Terhune CJ, Alston WK. Interaction of age and levofloxacin exposure on the incidence of clostridium difficile infection. Infect Dis Clin Pract. 2011;19:262-4. doi:10.1097/IPC.0b013e31820994a2

151 Manian FA, Griesnauer S, Bryant A. Implementation of hospital-wide enhanced terminal cleaning of targeted patient rooms and its impact on endemic Clostridium difficile infection rates. Am J Infect Control. 2013;41:537-41. Medline:23219675 doi:10.1016/j.ajic.2012.06.014

152 Marco-Martinez J, Barba-Martin R, Plaza-Canteli S, Canora-Lebrato J, Mendez-Baillon M, Miguel-Yanes JMd, et al. Clostridium difficile infections in Spanish Internal Medicine departments during the period 2005-2010: the burden of the disease. Enferm Infecc Microbiol Clin. 2015;33:16-21. Medline:24679445

153 Marwick CA, Yu N, Lockhart MC, McGuigan CC, Wiuff C, Davey PG, et al. Community-associated Clostridium difficile infection among older people in Tayside, Scotland, is associated with antibiotic exposure and care home residence: cohort study with nested case-control. J Antimicrob Chemother. 2013;68:2927-33. Medline:23825381 doi:10.1093/ jac/dkt257

154 Mattner F, Winterfeld I, Knobloch J, Solbach W. Successful bundle of prevention measures against a high CDAD incidence at a university hospital. Hyg Med. 2008;33:346-52.

155 Centers for Disease Control and Prevention (CDC). Vital signs: preventing Clostridium difficile infections. Morbidity and Mortality Weekly Report. 2012;61:157-62. Medline:22398844

156 McDonald LC, Owings M, Jernigan DB. Clostridium difficile infection in patients discharged from US short-stay hospitals, 1996-2003. Emerg Infect Dis. 2006;12:409-15. Medline:16704777 doi:10.3201/eid1205.051064

157 McFarland LV, Clarridge JE, Beneda HW, Raugi GJ. Fluoroquinolone use and risk factors for Clostridium difficile-associated disease within a Veterans Administration health care system. Clin Infect Dis. 2007;45:1141-51. Medline:17918075 doi: $10.1086 / 522187$

158 Mellace L, Consonni D, Jacchetti G, Del Medico M, Colombo R, Velati M, et al. Epidemiology of Clostridium difficile-associated disease in internal medicine wards in northern Italy. Intern Emerg Med. 2013;8:717-23. Medline:22249916 doi:10.1007/s11739-012-0752-6

159 Mertz D, Frei R, Plagge H, Battegay M, Widmer AF. Stronger correlation between antibiotic use and the incidence of Clostridium difficile determined by culture results instead of faecal toxin detection only. Eur J Clin Microbiol Infect Dis. 2010;29:1575-8. Medline:20706856 doi:10.1007/s10096-010-1022-z

160 Meyer E, Gastmeier P, Weizel-Kage D, Schwab F. Associations between nosocomial meticillin-resistant Staphylococcus aureus and nosocomial Clostridium difficile-associated diarrhoea in 89 German hospitals. J Hosp Infect. 2012;82:1816. Medline:23021304 doi:10.1016/j.jhin.2012.07.022

161 Mitchell B, Ware C, McGregor A, Brown S, Wells A. Clostridium difficile infection in Tasmanian public hospitals 2006 - 2010. Healthc Infect. 2011;16:101-6. doi:10.1071/HI11009

162 Mitchell BG. Clostridium difficile infection: Incidence in an Australian setting. Asian Nurs Res. 2014;8:213-8. doi:10.1016/j.anr.2014.07.003

163 Mitchell BG, Wilson F, McGregor A. An increase in community onset Clostridium difficile infection: A population-based study, Tasmania, Australia. Healthc Infect. 2012;17:127-32. doi:10.1071/HI12029

$164 \mathrm{MoH}$ Uruguay MdSPU. Infecciones por Clostridium difficile en hospitales centinela. 2012. Available: http://www.msp. gub.uy/sites/default/files/Informe_ICD_2012.pdf. Accessed: [01 March 2017].

165 Montoya M, Detorres O. Antimicrobial selection and its impact on the incidence of Clostridium difficile-associated diarrhea. J Pharm Pract. 2013;26:483-7. Medline:23940122 doi:10.1177/0897190013499524

166 Mori N, Yoshizawa S, Saga T, Ishii Y, Murakami H, Iwata M, et al. Incorrect diagnosis of Clostridium difficile infection in a university hospital in Japan. J Infect Chemother. 2015;21:718-22. Medline:26238001 doi:10.1016/j.jiac.2015.06.009

167 Murphy CR, Avery TR, Dubberke ER, Huang SS. Frequent hospital readmissions for Clostridium difficile infection and the impact on estimates of hospital-associated C. difficile burden. Infect Control Hosp Epidemiol. 2012;33:20-8. Medline:22173518 doi:10.1086/663209

168 Muto CA, Blank MK, Marsh JW, Vergis EN, O'Leary MM, Shutt KA, et al. Control of an outbreak of infection with the hypervirulent Clostridium difficile BI strain in a university hospital using a comprehensive "bundle" approach. Clin Infect Dis. 2007:45:1266-73. Medline:17968819 doi:10.1086/522654

169 Mylotte JM, Russell S, Sackett B, Vallone M, Antalek M. Surveillance for Clostridium difficile infection in nursing homes. J Am Geriatr Soc. 2013;61:122-5. Medline:23253029 doi:10.1111/jgs.12041

170 Nagaraja A, Visintainer P, Haas JP, Menz J, Wormser GP, Montecalvo MA. Clostridium difficile infections before and during use of ultraviolet disinfection. American Journal of Infection Control. 2015;43:940-5 6p.

171 National Institute for Health and Welfare. Infectious diseases in Finland 2013. Helsinki: Department of Infectious Disease Surveillance and Control, 2013. 
172 Novak A, Spigaglia P, Barbanti F, Goic-Barisic I, Tonkic M. First clinical and microbiological characterization of Clostridium difficile infection in a Croatian University Hospital. Anaerobe. 2014;30:18-23. Medline:25079669 doi:10.1016/j. anaerobe.2014.07.007

173 Nowak MA, Nelson RE, Breidenbach JL, Thompson PA, Carson PJ. Clinical and economic outcomes of a prospective antimicrobial stewardship program. Am J Health Syst Pharm. 2012;69:1500-8. Medline:22899745 doi:10.2146/ ajhp110603

174 Nseir W, Bishara J, Mograbi J, Mahamid M, Khalaila W, Taha M, et al. Do statins protect against the development of Clostridium difficile-associated diarrhoea? Journal of Antimicrobial Chemotherapy (JAC). 2013;68:1889-93 5p.

175 Oake N, Taljaard M, van Walraven C, Wilson K, Roth V, Forster AJ. The effect of hospital-acquired Clostridium difficile infection on in-hospital mortality. Arch Intern Med. 2010;170:1804-10. Medline:21059973 doi:10.1001/archinternmed.2010.405

176 O'Brien JA, Lahue BJ, Caro JJ, Davidson DM. The emerging infectious challenge of Clostridium difficile-associated disease in Massachusetts hospitals: clinical and economic consequences. Infect Control Hosp Epidemiol. 2007;28:121927. Medline:17926270 doi:10.1086/522676

177 Paltansing S, van den Berg RJ, Guseinova RA, Visser CE, van der Vorm ER, Kuijper EJ. Characteristics and incidence of Clostridium difficile-associated disease in The Netherlands, 2005. Clin Microbiol Infect. 2007;13:1058-64. Medline:17922780 doi:10.1111/j.1469-0691.2007.01793.x

178 Passaretti CL, Otter JA, Reich NG, Myers J, Shepard J, Ross T, et al. An evaluation of environmental decontamination with hydrogen peroxide vapor for reducing the risk of patient acquisition of multidrug-resistant organisms. Clin Infect Dis. 2013;56:27-35. Medline:23042972 doi:10.1093/cid/cis839

179 Pawar D, Tsay R, Nelson DS, Elumalai MK, Lessa FC, Clifford McDonald L, et al. Burden of Clostridium difficile infection in long-term care facilities in Monroe County, New York. Infect Control Hosp Epidemiol. 2012;33:1107-12. Medline:23041808 doi:10.1086/668031

180 Public Health Agency of Canada. Healthcare-associated Clostridium difficile infection in Canadian acute-care hospitals. 2012. Available: http://www.phac-aspc.gc.ca/id-mi/c-difficile-sum-res-eng.php. Accessed: [01 March 2017].

181 Public Health England. Clostridium difficile: annual data. 2004-15. Available: http://webarchive.nationalarchives.gov. uk. Accessed: [01 March 2017].

182 Pituch H, Obuch-Woszczatynski P, Lachowicz D, Wultanska D, Karpinski P, Mlynarczyk G, et al. Hospital-based Clostridium difficile infection surveillance reveals high proportions of PCR ribotypes 027 and 176 in different areas of Poland, 2011 to 2013. Euro Surveill. 2015;20:30025. Medline:26536049 doi:10.2807/1560-7917.ES.2015.20.38.30025

183 Popovich KJ, Hota B, Hayes R, Weinstein RA, Hayden MK. Effectiveness of routine patient cleansing with chlorhexidine gluconate for infection prevention in the medical intensive care unit. Infect Control Hosp Epidemiol. 2009;30:959-63. Medline:19712033 doi:10.1086/605925

184 Price MF, Dao-Tran T, Garey KW, Graham G, Gentry LO, Dhungana L, et al. Epidemiology and incidence of Clostridium difficile-associated diarrhoea diagnosed upon admission to a university hospital. J Hosp Infect. 2007;65:42-6. Medline:17145108 doi:10.1016/j.jhin.2006.08.010

185 Rajabally NM, Pentecost M, Pretorius G, Whitelaw A, Mendelson M, Watermeyer G. The Clostridium difficile problem: a South African tertiary institution's prospective perspective. South African Medical Journal Suid-Afrikaanse Tydskrif Vir Geneeskunde. 2013;103:168-72. Medline:23472693

186 Reddy S, Taori S, Poxton IR. Changes in laboratory and clinical workload for Clostridium difficile infection from 2003 to 2007 in hospitals in Edinburgh. Clin Microbiol Infect. 2010;16:340-6. Medline:20222891 doi:10.1111/j.14690691.2010.03141.x

187 Reigadas E, Alcalá L, Marín M, Burillo A, Mu囚oz P, Bouza E. Missed diagnosis of Clostridium difficile infection; a prospective evaluation of unselected stool samples. J Infect. 2015;70:264-72. Medline:25452039 doi:10.1016/j. jinf.2014.10.013

188 Reveles KR, Lee GC, Boyd NK, Frei CR. The rise in Clostridium difficile infection incidence among hospitalized adults in the United States: 2001-2010. Am J Infect Control. 2014;42:1028-32. Medline:25278388 doi:10.1016/j. ajic.2014.06.011

189 Rhee SM, Tsay R, Nelson DS, Van Wijngaarden E, Dumyati G. Clostridium difficile in the pediatric population of Monroe county, New York. J Pediatric Infect Dis Soc. 2014;3:183-8. Medline:26625381 doi:10.1093/jpids/pit091

190 Ricciardi R, Harriman K, Baxter NN, Hartman LK, Town RJ, Virnig BA. Predictors of Clostridium dificile colitis infections in hospitals. Epidemiol Infect. 2008;136:913-21. Medline:17686193 doi:10.1017/S0950268807009387

191 Ricciardi R, Rothenberger DA, Madoff RD, Baxter NN. Increasing prevalence and severity of Clostridium difficile colitis in hospitalized patients in the United States. Arch Surg. 2007;142:624-31, discussion 31. Medline:17638799 doi:10.1001/archsurg.142.7.624

192 National Reference Laboratory Netherlands RIVM. Annual Report of the National Reference Laboratory for Clostridium difficile and results of the sentinel surveillance. 2012-14. Available: http://www.rivm.nl/. Accessed: [01 March 2017].

193 Rodriguez-Pardo D, Almirante B, Bartolome RM, Pomar V, Mirelis B, Navarro F, et al. Epidemiology of Clostridium difficile infection and risk factors for unfavorable clinical outcomes: results of a hospital-based study in Barcelona, Spain. J Clin Microbiol. 2013;51:1465-73. Medline:23447638 doi:10.1128/JCM.03352-12

194 Rogers MA, Greene MT, Saint S, Chenoweth CE, Malani PN, Trivedi I, et al. Higher rates of Clostridium difficile infection among smokers. PLoS One. 2012;7:e42091. Medline:22848714 doi:10.1371/journal.pone.0042091 
195 Sabbah MA, Schorr C, Czosnowski QA, Hunter K, Torjman MC, Fraimow HS, et al. Risk of Clostridium difficile infection in intensive care unit patients with sepsis exposed to metronidazole. Infect Dis (Lond). 2015;47:197-202. Medline:25622943 doi:10.3109/00365548.2014.978890

196 Salazar M, Garey KW, Jiang ZD, Dao-Tran T, Dupont H. Changing Clostridium difficile infection testing and treatment trends at a large tertiary care teaching hospital. Pharm World Sci. 2009;31:565-71. Medline:19657721 doi:10.1007/ s11096-009-9316-x

197 Salgado CD, Mauldin PD, Fogle PJ, Bosso JA. Analysis of an outbreak of Clostridium difficile infection controlled with enhanced infection control measures. Am J Infect Control. 2009;37:458-64. Medline:19243859 doi:10.1016/j. ajic.2008.11.010

198 Salva S, Duran N, Rodriguez V, Nieto L, Serra J, Rello J, et al. Clostridium difficile in the ICU: study of the incidence, recurrence, clinical characteristics and complications in a university hospital. Med Intensiva. 2014;38:140-5. Medline:23769945 doi:10.1016/j.medin.2013.03.012

199 Sammons JS, Localio R, Xiao R, Coffin SE, Zaoutis T. Clostridium difficile infection is associated with increased risk of death and prolonged hospitalization in children. Clin Infect Dis. 2013;57:1-8. Medline:23532470 doi:10.1093/cid/ cit 155

200 Sansone S, Aschbacher R, Staffler M, Bombonato M, Girardi F, Larcher C, et al. Nosocomial diarrhoea in adult medical patients: the role of Clostridium difficile in a North Italian acute care teaching hospital. J Prev Med Hyg. 2009;50:11720. Medline:20099443

201 Santiago B, Guerra L, Garcia-Morin M, Gonzalez E, Gonzalvez A, Izquierdo G, et al. Clostridium difficile isolation in children hospitalized with diarrhea. An Pediatr (Barc). 2015;82:417-25. Medline:25217386 doi:10.1016/j.anpedi.2014.07.015

202 Sathyendran V, McAuliffe GN, Swager T, Freeman JT, Taylor SL, Roberts SA. Clostridium difficile as a cause of healthcare-associated diarrhoea among children in Auckland, New Zealand: clinical and molecular epidemiology. Eur J Clin Microbiol Infect Dis. 2014;33:1741-7. Medline:24810967 doi:10.1007/s10096-014-2139-2

203 Schmiedeskamp M, Harpe S, Polk R, Oinonen M, Pakyz A. Use of International Classification of Diseases, Ninth Revision, Clinical Modification codes and medication use data to identify nosocomial Clostridium difficile infection. Infect Control Hosp Epidemiol. 2009;30:1070-6. Medline:19803724 doi:10.1086/606164

204 Schwartz KL, Darwish I, Richardson SE, Mulvey MR, Thampi N. Severe clinical outcome is uncommon in Clostridium difficile infection in children: a retrospective cohort study. BMC Pediatr. 2014;14:28. Medline:24485120 doi:10.1186/1471-2431-14-28

205 Shaklee J, Zerr DM, Elward A, Newland J, Leckerman K, Asti L, et al. Improving surveillance for pediatric Clostridium difficile infection: derivation and validation of an accurate case-finding tool. Pediatr Infect Dis J. 2011;30:e38-40. Medline:21079527 doi:10.1097/INF.0b013e3182027c22

206 Shears P, Prtak L, Duckworth R. Hospital-based epidemiology: a strategy for 'dealing with Clostridium difficile'. J Hosp Infect. 2010;74:319-25. Medline:19726105 doi:10.1016/j.jhin.2009.07.009

207 Siller-Ruiz M, Calvo-Garcia N, Hernandez-Egido S, Maria-Blazquez A, de Frutos-Serna M, Garcia-Sanchez JE. Epidemiology of Clostridium difficile-associated disease (CDAD) in Salamanca. Rev Esp Quimioter. 2014;27:122-6. Medline:24940894

208 Silva M Jr, Marra AR, Camargo TZ, Almeida SM, Siqueira I, Correa L, et al. Secular trends in the epidemiology of Clostridium difficile infection (CDI): relationship with alcohol gel and antimicrobial usage in a hospital. Int J Infect Dis. 2013;17:e418-21. Medline:23419978 doi:10.1016/j.ijid.2012.12.022

209 Skyum F, Karim Abed O, Backer Mogensen C. Clinical information on admission is insufficient to determine the appropriate isolation regimen for acute gastroenteritis. Dan Med J. 2014;61:A4850. Medline:24947622

210 Slimings C, Armstrong P, Beckingham WD, Bull AL, Hall L, Kennedy KJ, et al. Increasing incidence of Clostridium difficile infection, Australia, 2011-2012. Med J Aust. 2014;200:272-6. Medline:24641152 doi:10.5694/mja13.11153

211 Smith LC, Ratard R. Clostridium difficile hospitalizations in Louisiana: a 10 year review. J La State Med Soc. 2011;163:1925. Medline:21954651

212 Soes LM, Holt HM, Bottiger B, Nielsen HV, Torpdahl M, Nielsen EM, et al. The incidence and clinical symptomatology of Clostridium difficile infections in a community setting in a cohort of Danish patients attending general practice. Eur J Clin Microbiol Infect Dis. 2014;33:957-67. Medline:24352841 doi:10.1007/s10096-013-2033-3

213 Sohn S, Climo M, Diekema D, Fraser V, Herwaldt L, Marino S, et al. Varying rates of Clostridium difficile-associated diarrhea at prevention epicenter hospitals. Infect Control Hosp Epidemiol. 2005;26:676-9. Medline:16156322 doi:10.1086/502601

214 Song X, Bartlett JG, Speck K, Naegeli A, Carroll K, Perl TM. Rising economic impact of clostridium difficile-associated disease in adult hospitalized patient population. Infect Control Hosp Epidemiol. 2008;29:823-8. Medline:18643746 doi: $10.1086 / 588756$

215 Souza Dias MB, Yamashiro J, Borrasca VL, Stempliuk VA, Araújo MRE, Costa SF, et al. Pseudo-outbreak of Clostridium difficile associated diarrhea (CDAD) in a tertiary-care hospital. Rev Inst Med Trop S囚o Paulo. 2010;52:133-7. Medline:20602022 doi:10.1590/S0036-46652010000300004

216 Statens Serum Institut SSI. Surveillance of hospital-acquired Clostridium difficile infection through HAIBA. 2015. Available: http://www.ssi.dk/English/News/EPI-NEWS/2015/No\%2010\%20-\%202015.aspx. Accessed: [01 March 2017].

217 Starzengruber P, Segagni Lusignani L, Wrba T, Mitteregger D, Indra A, Graninger W, et al. Severe Clostridium difficile infection: incidence and risk factors at a tertiary care university hospital in Vienna, Austria. Wien Klin Wochenschr. 2014;126:427-30. Medline:24903143 doi:10.1007/s00508-014-0549-x 
218 Stausberg J, Hasford J. Drug-related admissions and hospital-acquired adverse drug events in Germany: a longitudinal analysis from 2003 to 2007 of ICD-10-coded routine data. BMC Health Serv Res. 2011;11:134. Medline:21619706 doi:10.1186/1472-6963-11-134

219 Suzuki H, Senda J, Yamashita K, Tokuda Y, Kanesaka Y, Kotaki N, et al. Impact of intensive infection control team activities on the acquisition of methicillin-resistant Staphylococcus aureus, drug-resistant Pseudomonas aeruginosa and the incidence of Clostridium difficile-associated disease. J Infect Chemother. 2013;19:1047-52. Medline:23715827 doi:10.1007/s10156-013-0621-x

220 Tan ET, Robertson CA, Brynildsen S, Bresnitz E, Tan C, McDonald LC. Clostridium difficile-associated disease in New Jersey hospitals, 2000-2004. Emerg Infect Dis. 2007;13:498-500. Medline:17552112 doi:10.3201/eid1303.060294

221 Tan XQ, Verrall AJ, Jureen R, Riley TV, Collins DA, Lin RT, et al. The emergence of community-onset Clostridium difficile infection in a tertiary hospital in Singapore: a cause for concern. Int J Antimicrob Agents. 2014;43:47-51. Medline:24290727 doi:10.1016/j.ijantimicag.2013.09.011

222 Taori SK, Wroe A, Hardie A, Gibb AP, Poxton IR. A prospective study of community-associated Clostridium difficile infections: the role of antibiotics and co-infections. J Infect. 2014;69:134-44. Medline:24780765 doi:10.1016/j. jinf.2014.04.002

223 Tartof SY, Rieg GK, Wei R, Tseng H, Jacobsen SJ, Yu KC. A comprehensive assessment across the healthcare continuum: risk of hospital-associated Clostridium difficile infection due to outpatient and inpatient antibiotic exposure. Infect Control Hosp Epidemiol. 2015;36:1409-16. Medline:26387888 doi:10.1017/ice.2015.220

224 Tartof SY, Yu KC, Wei R, Tseng HF, Jacobsen SJ, Rieg GK. Incidence of polymerase chain reaction-diagnosed Clostridium difficile in a large high-risk cohort, 2011-2012. Mayo Clin Proc. 2014;89:1229-38. Medline:25064782 doi:10.1016/j mayocp.2014.04.027

225 Teltsch DY, Hanley J, Loo V, Goldberg P, Gursahaney A, Buckeridge DL. Infection acquisition following intensive care unit room privatization. Arch Intern Med. 2011;171:32-8. Medline:21220658 doi:10.1001/archinternmed.2010.469

226 Thibault R, Graf S, Clerc A, Delieuvin N, Heidegger CP, Pichard C. Diarrhoea in the ICU: respective contribution of feeding and antibiotics. Crit Care. 2013;17:R153. Medline:23883438 doi:10.1186/cc12832

227 Tschudin-Sutter S, Tamma PD, Naegeli AN, Speck KA, Milstone AM, Perl TM. Distinguishing community-associated from hospital-associated Clostridium difficile infections in children: implications for public health surveillance. Clin Infect Dis. 2013;57:1665-72. Medline:24046303 doi:10.1093/cid/cit581

228 Van Gessel H. Measuring the incidence of Clostridium difficile-associated diarrhoea in a group of Western Australian hospitals. Healthcare Infection. 2008;13:56-62 7p.

229 VerLee KE, Finks JL, Wilkins MJ, Wells EV. Michigan Clostridium difficile hospital discharges: frequency, mortality, and charges, 2002-2008. [Erratum appears in Public Health Rep. 2015 Jul-Aug;130(4):301; PMID: 26345610]. Public Health Rep. 2012;127:62-71. Medline:22298923 doi:10.1177/003335491212700107

230 Vernaz N, Hill K, Leggeat S, Nathwani D, Philips G, Bonnabry P, et al. Temporal effects of antibiotic use and Clostridium difficile infections. J Antimicrob Chemother. 2009;63:1272-5. Medline:19372170 doi:10.1093/jac/dkp128

231 Vesteinsdottir I, Gudlaugsdottir S, Einarsdottir R, Kalaitzakis E, Sigurdardottir O, Bjornsson ES. Risk factors for Clostridium difficile toxin-positive diarrhea: a population-based prospective case-control study. Eur J Clin Microbiol Infect Dis. 2012;31:2601-10. Medline:22441775 doi:10.1007/s10096-012-1603-0

232 Wang X, Cai L, Yu R, Huang W, Zong Z. ICU-onset Clostridium difficile infection in a university hospital in China: a prospective cohort study. PLoS One. 2014;9:e111735. Electronic Resource. Medline:25372033 doi:10.1371/journal. pone.0111735

233 Weitzel-Kage D, Behnke M, Eckmanns T, Gastmeier P. Incidence of Clostridium-difficile-associated disease: first results of CDAD-KISS as component of the German nosocomial infection surveillance system. Hyg Med. 2008;33:353-6.

234 Welker JA, Bertumen JB. Toxin assay is more reliable than ICD-9 data and less time-consuming than chart review for public reporting of Clostridium difficile hospital case rates. J Hosp Med. 2012;7:170-5. Medline:22106004 doi:10.1002/ jhm.990

235 Wenisch JM, Schmid D, Kuo HW, Simons E, Allerberger F, Michl V, et al. Hospital-acquired Clostridium difficile infection: determinants for severe disease. Eur J Clin Microbiol Infect Dis. 2012;31:1923-30. Medline:22210266 doi:10.1007/ s10096-011-1522-5

236 Wilcox MH, Mooney L, Bendall R, Settle CD, Fawley WN. A case-control study of community-associated Clostridium difficile infection. J Antimicrob Chemother. 2008;62:388-96. Medline:18434341 doi:10.1093/jac/dkn163

237 Wilson AP, Smyth D, Moore G, Singleton J, Jackson R, Gant V, et al. The impact of enhanced cleaning within the intensive care unit on contamination of the near-patient environment with hospital pathogens: A randomized crossover study in critical care units in two hospitals. Critical Care Medicine. 2011;39:651-8 8p.

238 Yin J, Schweizer ML, Herwaldt LA, Pottinger JM, Perencevich EN. Benefits of universal gloving on hospital-acquired infections in acute care pediatric units. Pediatrics. 2013;131:e1515-20. Medline:23610206 doi:10.1542/peds.2012-3389

239 Young-Xu Y, Kuntz JL, Gerding DN, Neily J, Mills P, Dubberke ER, et al. Clostridium difficile infection among Veterans Health Administration patients. Infect Control Hosp Epidemiol. 2015;36:1038-45. Medline:26047207 doi:10.1017/ ice. 2015.138

240 Zahar JR, Schwebel C, Adrie C, Garrouste-Orgeas M, Francais A, Vesin A, et al. Outcome of ICU patients with Clostridium difficile infection. Crit Care. 2012;16:R215. Medline:23127327 doi:10.1186/cc11852

241 Zarowitz BJ, Allen C, O'Shea T, Strauss ME. Risk factors, clinical characteristics, and treatment differences between residents with and without nursing home- and non-nursing home-acquired Clostridium difficile Infection. J Manag Care Spec Pharm. 2015;21:585-95. Medline:26108383 
242 Zilberberg MD, Shorr AF, Kollef MH. Increase in adult Clostridium difficile-related hospitalizations and case-fatality rate, United States, 2000-2005. Emerg Infect Dis. 2008;14:929-31. Medline:18507904 doi:10.3201/eid1406.071447

243 Zilberberg MD, Tabak YP, Sievert DM, Derby KG, Johannes RS, Sun X, et al. Using electronic health information to risk-stratify rates of Clostridium difficile infection in US hospitals. Infect Control Hosp Epidemiol. 2011;32:649-55. Medline:21666394 doi:10.1086/660360

244 Zilberberg MD, Tillotson GS, McDonald C. Clostridium difficile infections among hospitalized children, United States, 1997-2006. Emerg Infect Dis. 2010;16:604-9. Medline:20350373 doi:10.3201/eid1604.090680

245 Gould CV, Edwards JR, Cohen J, Bamberg WM, Clark LA, Farley MM, et al. Effect of nucleic acid amplification testing on population-based incidence rates of Clostridium difficile infection. Clin Infect Dis. 2013;57:1304-7. Medline:23899677 doi:10.1093/cid/cit492

246 van Dorp SM, Kinross P, Gastmeier P, Behnke M, Kola A, Delmee M, et al. Standardised surveillance of Clostridium Difficile Infection in European acute care hospitals: A pilot study, 2013. Euro Surveill. 2016;21:30293. Medline:27472820 doi:10.2807/1560-7917.ES.2016.21.29.30293

247 Davies K, Davis G, Barbut F, Eckert C, Petrosillo N, Wilcox MH. Variability in testing policies and impact on reported Clostridium difficile infection rates: results from the pilot Longitudinal European Clostridium difficile Infection Diagnosis surveillance study (LuCID). Eur J Clin Microbiol Infect Dis. 2016;35:1949-56. Medline:27590621 doi:10.1007/ s10096-016-2746-1

248 Kola A, Wiuff C, Akerlund T, van Benthem BH, Coignard B, Lyytikainen O, et al. Survey of Clostridium difficile infection surveillance systems in Europe, 2011. Euro Surveill. 2016;21:30291. Medline:27469420 doi:10.2807/15607917.ES.2016.21.29.30291

249 Burke KE, Lamont JT. Clostridium difficile infection: a worldwide disease. Gut Liver. 2014;8:1-6. Medline:24516694 doi:10.5009/gnl.2014.8.1.1

250 Balassiano IT, Yates EA, Domingues RM, Ferreira EO. Clostridium difficile: a problem of concern in developed countries and still a mystery in Latin America. J Med Microbiol. 2012;61:169-79. Medline:22116982 doi:10.1099/jmm.0.037077-0

251 Hawkey PM, Marriott C, Liu W, Jian Z, Gao Q, Ling K, et al. Molecular epidemiology of Clostridium difficile infection in a major Chinese hospital: an underrecognized problem in Asia? J Clin Microbiol. 2013;51:3308-13. Medline:23903542 doi:10.1128/JCM.00587-13

252 He M, Miyajima F, Roberts P, Ellison L, Pickard DJ, Martin MJ, et al. Emergence and global spread of epidemic healthcare-associated Clostridium difficile. Nat Genet. 2013;45:109-13. Medline:23222960 doi:10.1038/ng.2478

253 Lawes T, Lopez-Lozano JM, Nebot CA, Macartney G, Subbarao-Sharma R, Wares KD, et al. Effect of a national 4C antibiotic stewardship intervention on the clinical and molecular epidemiology of Clostridium difficile infections in a region of Scotland: a non-linear time-series analysis. Lancet Infect Dis. 2017;17:194-206. Medline:27825595 doi:10.1016/ S1473-3099(16)30397-8

254 Zilberberg MD, Shorr AF, Jesdale WM, Tjia J, Lapane K. Recurrent Clostridium difficile infection among Medicare patients in nursing homes: A population-based cohort study. Medicine (Baltimore). 2017;96:e6231. Medline:28272217 doi:10.1097/MD.0000000000006231

255 Lees EA, Miyajima F, Pirmohamed M, Carrol ED. The role of Clostridium difficile in the paediatric and neonatal gut - a narrative review. Eur J Clin Microbiol Infect Dis. 2016;35:1047-57. Medline:27107991 doi:10.1007/s10096-0162639-3

256 McFarland LV, Ozen M, Dinleyici EC, Goh S. Comparison of pediatric and adult antibiotic-associated diarrhea and Clostridium difficile infections. World J Gastroenterol. 2016;22:3078-104. Medline:27003987 doi:10.3748/wjg.v22. i1 1.3078

257 Nylund CM, Eide M, Gorman GH. Association of Clostridium difficile Infections with Acid Suppression Medications in Children. Journal of Pediatrics. 2014;165:979-84.e1 1p.

258 Le Saux N, Gravel D, Mulvey MR, Dennis J, Yasseen AS III, Barrowman N, et al. Pediatric Clostridium difficile infection: 6-year active surveillance in a defined patient population. Infect Control Hosp Epidemiol. 2014;35:904-6. Medline:24915227 doi:10.1086/676875

259 Karanika S, Paudel S, Zervou FN, Grigoras C, Zacharioudakis IM, Mylonakis E. Prevalence and Clinical Outcomes of Clostridium difficile Infection in the Intensive Care Unit: A Systematic Review and Meta-Analysis. Open Forum Infect Dis. 2015;3:ofv186. Medline:26788544 doi:10.1093/ofid/ofv186

260 Lofgren ET, Cole SR, Weber DJ, Anderson DJ, Moehring RW. Hospital-acquired Clostridium difficile infections: estimating all-cause mortality and length of stay. Epidemiology. 2014;25:570-5. Medline:24815305 doi:10.1097/ EDE.0000000000000119

261 Hunter JC, Mu Y, Dumyati GK, Farley MM, Winston LG, Johnston HL, et al. Burden of Nursing Home-Onset Clostridium difficile Infection in the United States: Estimates of Incidence and Patient Outcomes. Open Forum Infect Dis. 2016;3:ofv196. Medline:26798767 doi:10.1093/ofid/ofv196

262 Daneman N, Bronskill SE, Gruneir A, Newman AM, Fischer HD, Rochon PA, et al. Variability in Antibiotic Use Across Nursing Homes and the Risk of Antibiotic-Related Adverse Outcomes for Individual Residents. JAMA Intern Med. 2015;175:1331-9. Medline:26121537 doi:10.1001/jamainternmed.2015.2770

263 Banks A, Brown DJ, Mather H, Coia JE, Wiuff C. Sentinel community Clostridium difficile infection (CDI) surveillance in Scotland, April 2013 to March 2014. Anaerobe. 2016;37:49-53. Medline:26708405 doi:10.1016/j.anaerobe. 2015.12 .008 